\title{
LEVEL II SCOUR ANALYSIS FOR BRIDGE 34 (WWINTH00370034) on TOWN HIGHWAY 37, crossing MILL BROOK, WEST WINDSOR, VERMONT
}

Open-File Report 98-570

Prepared in cooperation with

VERMONT AGENCY OF TRANSPORTATION

and

FEDERAL HIGHWAY ADMINISTRATION

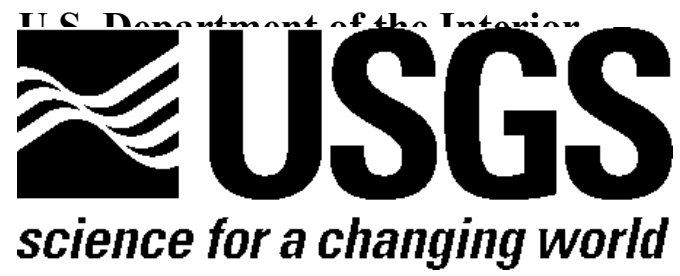




\section{LEVEL II SCOUR ANALYSIS FOR BRIDGE 34 (WWINTH00370034) on TOWN HIGHWAY 37, crossing MILL BROOK, WEST WINDSOR, VERMONT \\ By ERICK M. BOEHMLER AND EMILY C. WILD}

U.S. Geological Survey Open-File Report 98-570

Prepared in cooperation with

VERMONT AGENCY OF TRANSPORTATION and

FEDERAL HIGHWAY ADMINISTRATION 


\title{
U.S. DEPARTMENT OF THE INTERIOR BRUCE BABBITT, Secretary
}

\author{
U.S. GEOLOGICAL SURVEY
}

Thomas J. Casadevall, Acting Director

For additional information write to:

District Chief

U.S. Geological Survey 361 Commerce Way

Pembroke, NH 03275-3718
Copies of this report may be purchased from:

U.S. Geological Survey

Branch of Information Services

Open-File Reports Unit

Box 25286

Denver, CO 80225-0286 


\section{CONTENTS}

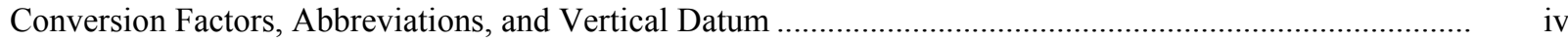

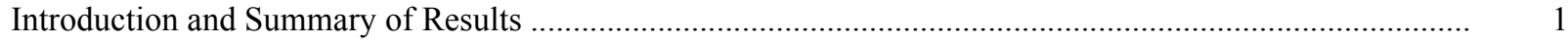

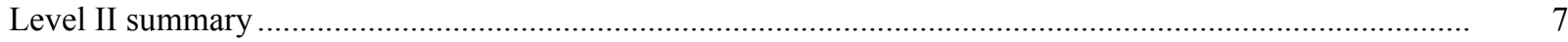

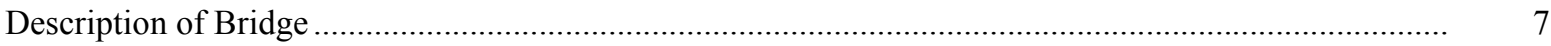

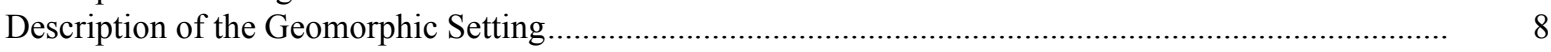

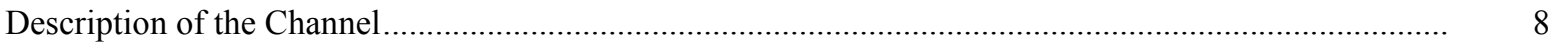

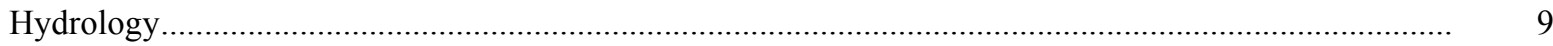

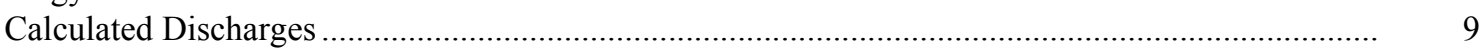

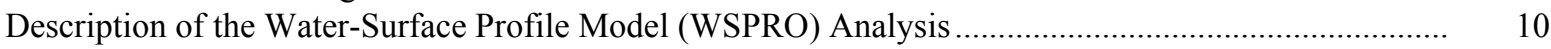

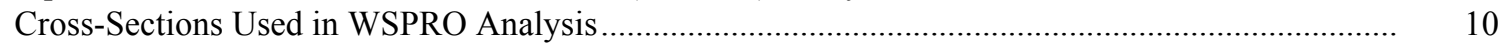

Data and Assumptions Used in WSPRO Model ........................................................................ 11

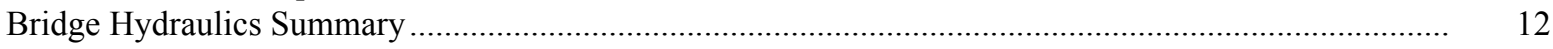

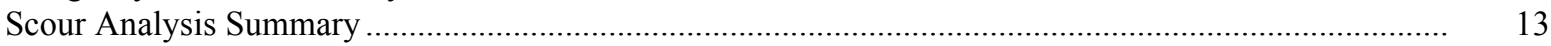

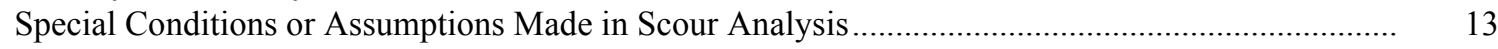

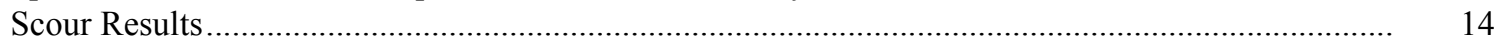

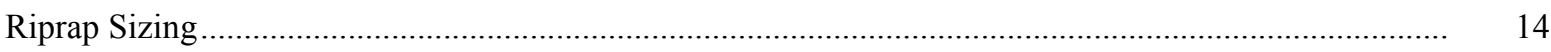

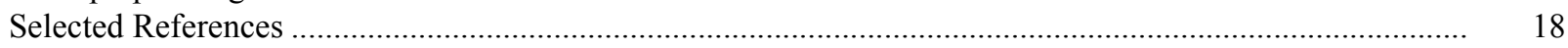

Appendices:

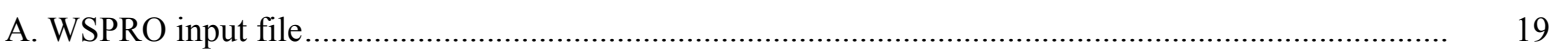

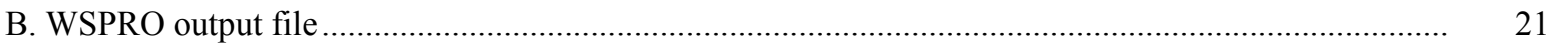

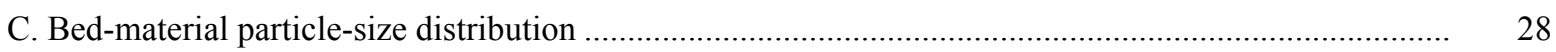

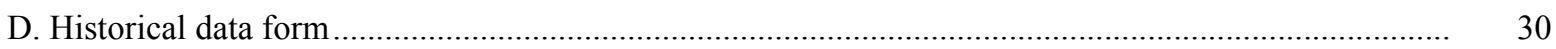

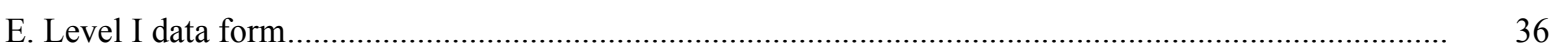

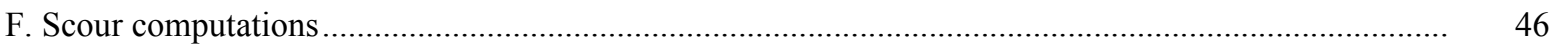

\section{FIGURES}

1. Map showing location of study area on USGS 1:24,000 scale map

2. Map showing location of study area on Vermont Agency of Transportation town highway map

3. Structure WWINTH00370034 viewed from upstream (June 5, 1996).

4

4. Downstream channel viewed from structure WWINTH00370034 (June 5, 1996)

5. Upstream channel viewed from structure WWINTH00370034 (June 5, 1996)

6. Structure WWINTH00370034 viewed from downstream (June 5, 1996).

7. Water-surface profiles for the 100- and 500-year discharges at structure

WWINTH00370034 on Town Highway 37, crossing Mill Brook,

West Windsor, Vermont....... 1

8
0 46

elevations for the 100- and 500-year discharges at structure

WWINTH00370034 on Town Highway 37, crossing Mill Brook,

West Windsor, Vermont.

\section{TABLES}

1. Remaining footing/pile depth at abutments for the 100-year discharge at structure

WWINTH00370034 on Town Highway 37, crossing Mill Brook,

West Windsor, Vermont .....

2. Remaining footing/pile depth at abutments for the 500-year discharge at structure WWINTH00370034 on Town Highway 37, crossing Mill Brook,

West Windsor, Vermont 


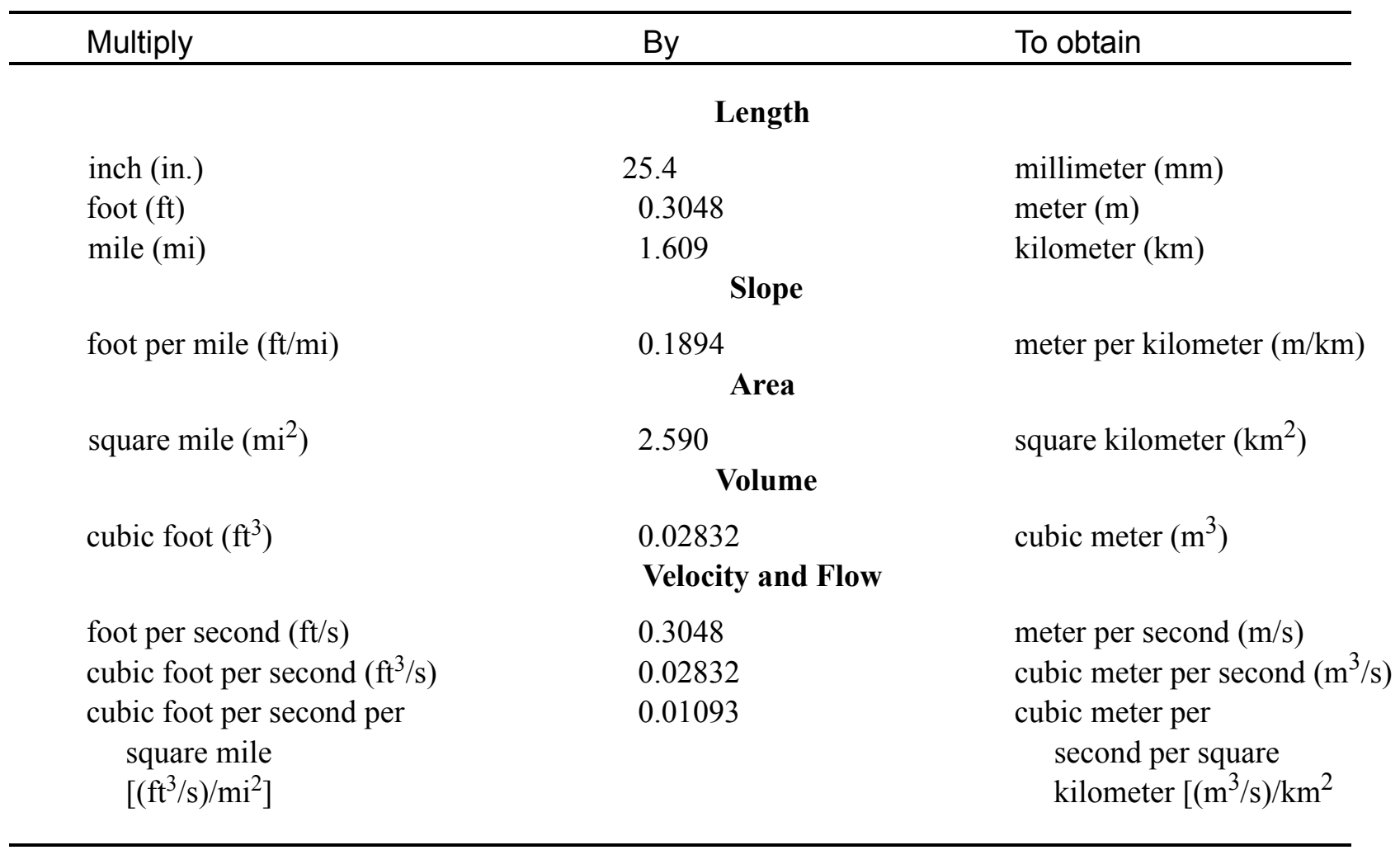

\section{OTHER ABBREVIATIONS}

$\begin{array}{lrlr}\mathrm{BF} & \text { bank full } & \text { LWW } & \text { left wingwall } \\ \mathrm{cfs} & \text { cubic feet per second } & \text { Max } & \text { maximum } \\ \mathrm{D}_{50} & \text { median diameter of bed material } & \text { MC } & \text { main channel } \\ \mathrm{DS} & \text { downstream } & \text { RAB } & \text { right abutment } \\ \mathrm{elev} & \text { elevation } & \text { RABUT } & \text { face of right abutment } \\ \mathrm{f} / \mathrm{p} & \text { flood plain } & \text { RB } & \text { right bank } \\ \mathrm{ft} & \text { square feet } & \text { ROB } & \text { right overbank } \\ \mathrm{ft} / \mathrm{ft} & \text { feet per foot } & \text { RWW } & \text { right wingwall } \\ \mathrm{FEMA} & \text { Federal Emergency Management Agency } & \text { TH } & \text { town highway } \\ \mathrm{FHWA} & \text { Federal Highway Administration } & \text { UB } & \text { under bridge } \\ \mathrm{JCT} & \text { junction } & \text { US } & \text { upstream } \\ \text { LAB } & \text { left abutment } & \text { USGS } & \text { United States Geological Survey } \\ \text { LABUT } & \text { face of left abutment } & \text { VTAOT } & \text { Vermont Agency of Transportation } \\ \text { LB } & \text { left bank } & \text { WSPRO } & \text { water-surface profile model } \\ \text { LOB } & \text { left overbank } & \text { yr } & \text { year }\end{array}$

In this report, the words "right" and "left" refer to directions that would be reported by an observer facing downstream. Sea level: In this report, "sea level" refers to the National Geodetic Vertical Datum of 1929-- a geodetic datum derived from a general adjustment of the first-order level nets of the United States and Canada, formerly called Sea Level Datum of 1929.

In the appendices, the above abbreviations may be combined. For example, USLB would represent upstream left bank. 


\title{
LEVEL II SCOUR ANALYSIS FOR BRIDGE 34 (WWINTH00370034) ON TOWN HIGHWAY 37, CROSSING MILL BROOK, WEST WINDSOR, VERMONT
}

\author{
By Erick M. Boehmler and Emily C. Wild
}

\section{INTRODUCTION AND SUMMARY OF RESULTS}

This report provides the results of a detailed Level II analysis of scour potential at structure WWINTH00370034 on Town Highway 37 crossing Mill Brook, West Windsor, Vermont (figures 1-8). A Level II study is a basic engineering analysis of the site, including a quantitative analysis of stream stability and scour (FHWA, 1993). Results of a Level I scour investigation also are included in appendix $\mathrm{E}$ of this report. A Level I investigation provides a qualitative geomorphic characterization of the study site. Information on the bridge, gleaned from Vermont Agency of Transportation (VTAOT) files, was compiled prior to conducting Level I and Level II analyses and is found in appendix D.

The site is in the New England Upland section of the New England physiographic province in east-central Vermont. The $16.6-\mathrm{mi}^{2}$ drainage area is in a predominantly rural and forested basin. In the vicinity of the study site, the surface cover is pasture except for the upstream left bank where there is mostly shrubs and brush.

In the study area, Mill Brook has a sinuous channel with a slope of approximately $0.003 \mathrm{ft} /$ $\mathrm{ft}$, an average channel top width of $52 \mathrm{ft}$ and an average bank height of $5 \mathrm{ft}$. The channel bed material ranges from sand to cobbles with a median grain size $\left(D_{50}\right)$ of $43.4 \mathrm{~mm}(0.142 \mathrm{ft})$. The geomorphic assessment at the time of the Level I and Level II site visit on June 5, 1996, indicated that the reach was laterally unstable. Point bars were observed upstream and downstream of this site. Furthermore, slip failure of the bank material was noted downstream at a cut-bank on the left side of the channel across from a point bar.

The Town Highway 37 crossing of Mill Brook is a 37-ft-long, one-lane covered bridge consisting of one 32-foot wood thru-truss span (Vermont Agency of Transportation, written communication, March 23, 1995). The opening length of the structure parallel to the bridge face is $29.6 \mathrm{ft}$. The bridge is supported by vertical, laid-up stone abutment walls with concrete facing and laid-up stone wingwalls. The channel is skewed approximately 10 degrees to the opening while the opening-skew-to-roadway is zero degrees. 
A scour hole $1.5 \mathrm{ft}$ deeper than the mean thalweg depth was observed along the right abutment during the Level I assessment. Scour protection measures at the site included type-3 (less than 48 inches diameter) and type-4 (less than 60 inches diameter) stone fill. Type-3 stone fill was observed along the upstream right bank and along the right abutments. Type-4 stone fill was observed at the upstream end of the upstream right wingwall. Additional details describing conditions at the site are included in the Level II Summary and appendices D and E.

Scour depths and recommended rock rip-rap sizes were computed using the general guidelines described in Hydraulic Engineering Circular 18 (Richardson and Davis, 1995) for the 100- and 500-year discharges. In addition, the incipient roadway-overtopping discharge was determined and analyzed as another potential worst-case scour scenario. Total scour at a highway crossing is comprised of three components: 1) long-term streambed degradation; 2) contraction scour (due to accelerated flow caused by a reduction in flow area at a bridge) and; 3 ) local scour (caused by accelerated flow around piers and abutments). Total scour is the sum of the three components. Equations are available to compute depths for contraction and local scour and a summary of the results of these computations follows.

There was no contraction scour predicted for any of the modeled flows. Abutment scour at the left abutment ranged from 5.7 to $7.3 \mathrm{ft}$, while that at the right abutment ranged from 11.6 to $17.7 \mathrm{ft}$. The worst-case abutment scour occurred at the 500-year discharge. Additional information on scour depths and depths to armoring are included in the section titled "Scour Results." Scoured-streambed elevations, based on the calculated scour depths, are presented in tables 1 and 2. A cross-section of the scour computed at the bridge is presented in figure 8. Scour depths were calculated assuming an infinite depth of erosive material and a homogeneous particle-size distribution.

It is generally accepted that the Froehlich equation (abutment scour) gives "excessively conservative estimates of scour depths" (Richardson and Davis, 1995, p. 46). Usually, computed scour depths are evaluated in combination with other information including (but not limited to) historical performance during flood events, the geomorphic stability assessment, existing scour protection measures, and the results of the hydraulic analyses. Therefore, scour depths adopted by VTAOT may differ from the computed values documented herein. 


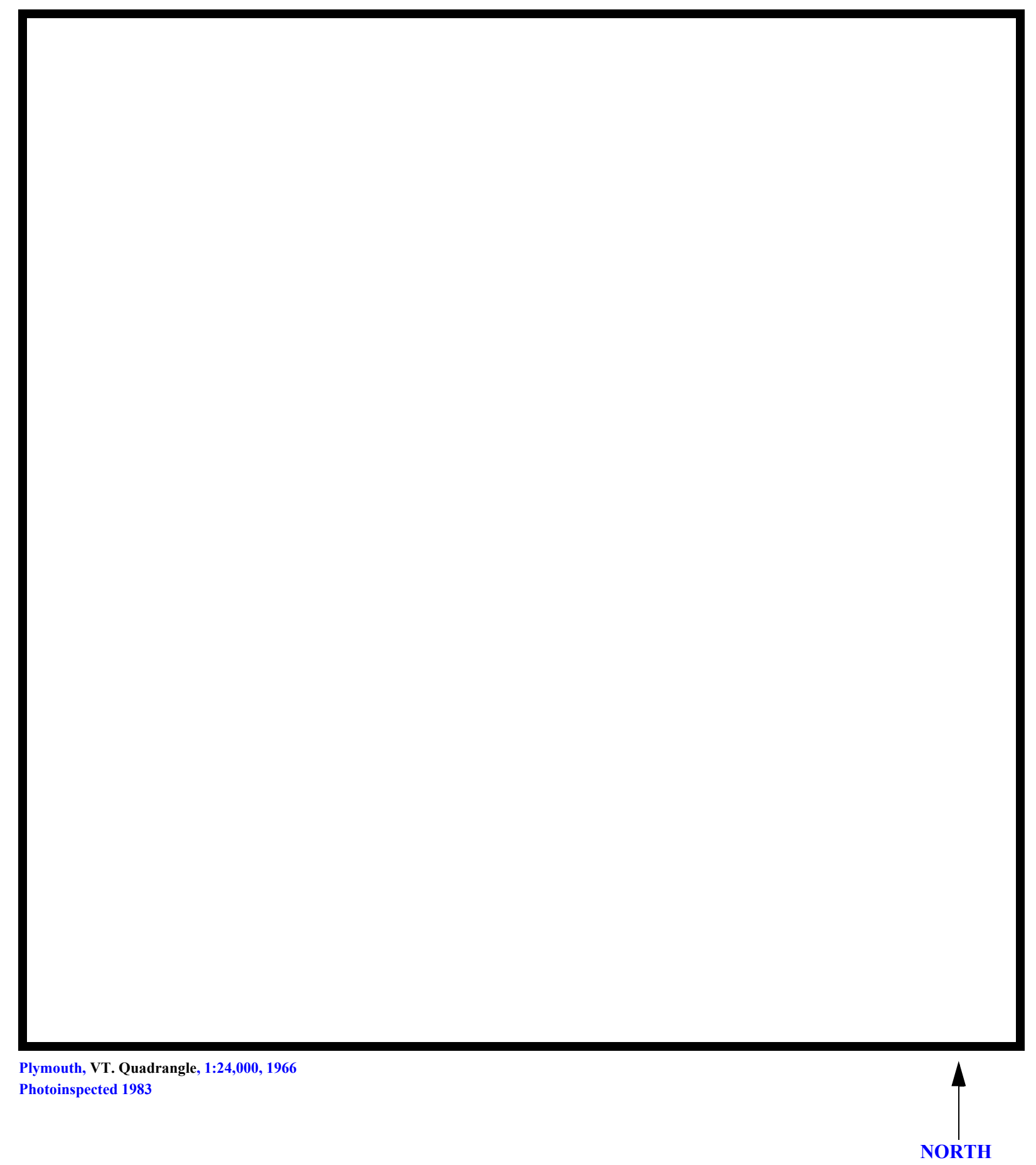

Figure 1. Location of study area on USGS 1:24,000 scale map. 
Figure 2. Location of study area on Vermont Agency of Transportation town highway map. 

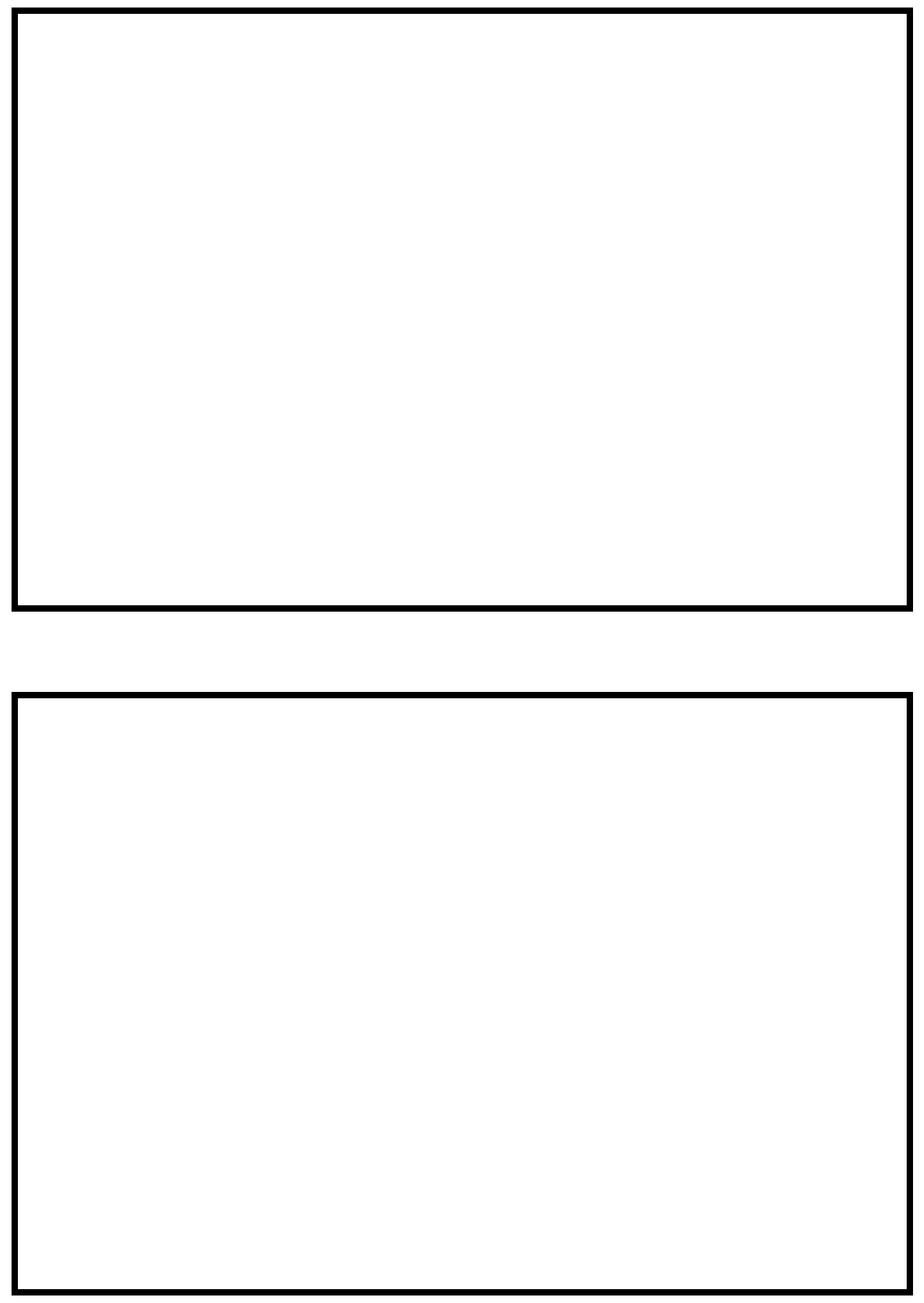

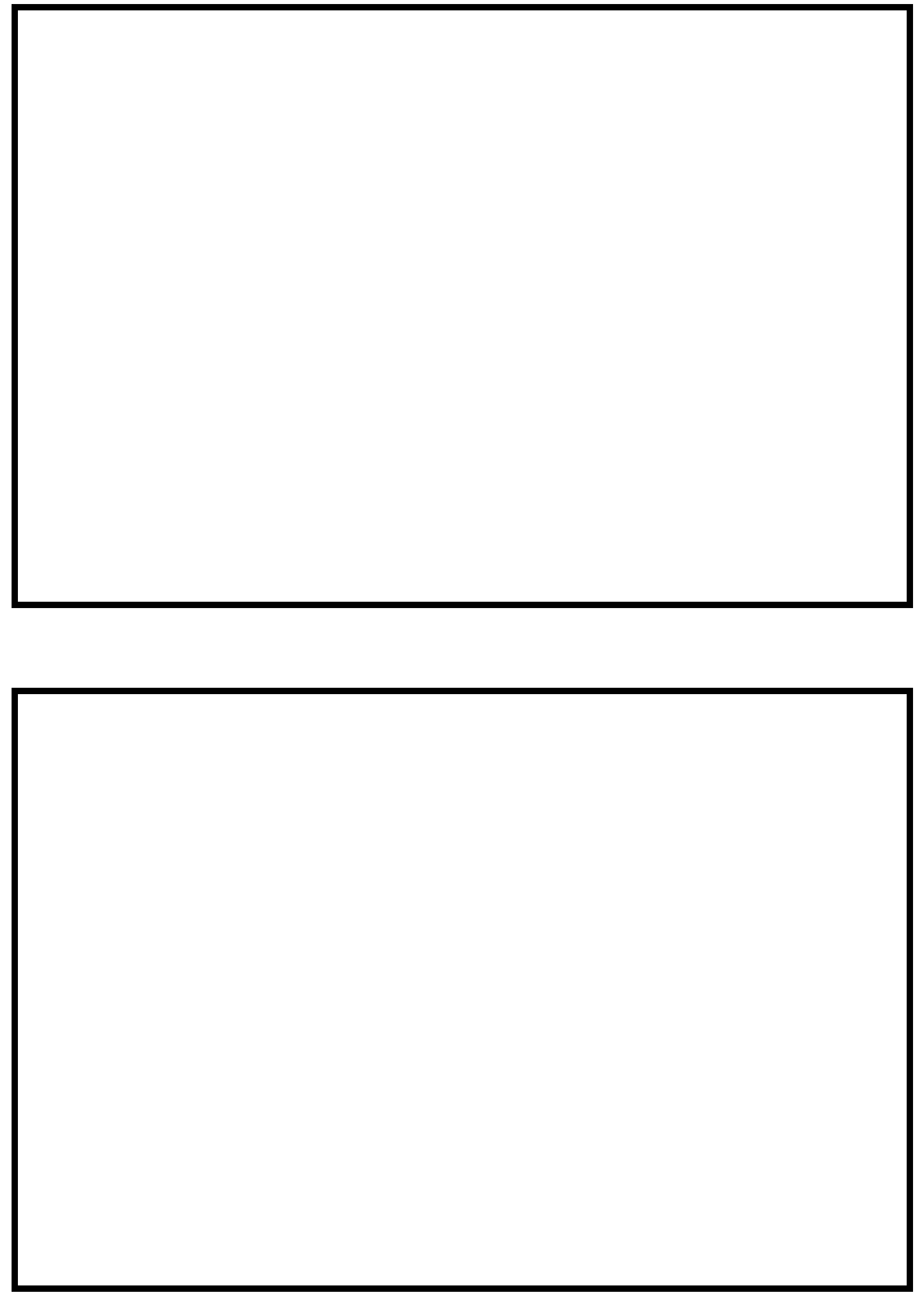


\section{LEVEL II SUMMARY}

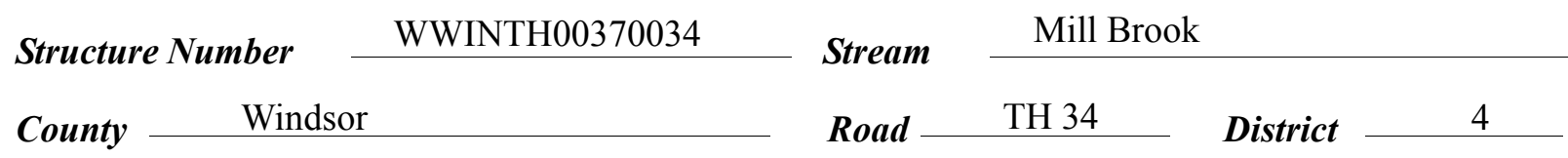

\section{Description of Bridge}

Bridge length $\frac{37}{} \boldsymbol{f t} \quad$ Bridge width $\frac{12.3}{f t}$ Max span length $\frac{32}{f t}$

Alignment of bridge to road (on curve or straight)

Abutment type Vertical, laid-up stone

Stone fill on abutment? Yes
Curved, right and straight, left

Sloping near vertical

\section{Embankment type} $6 / 5 / 96$

Drto af incnortinn. Type-3 along the abutments and the right bank upstream. nacaniminin af ata... fill

Type-4 stone fill was observed at the upstream end of the upstream right wingwall.

Abutments are laid-up stone wall with concrete facing

and laid-up stone wingwalls. A $1.5 \mathrm{ft}$ deep scour hole was observed along the right abutment.

Yes

$$
10 \quad \text { Yes }
$$

Angle

Is bridge skewed to flood flow according to There ' survey?

is a mild channel bend in the upstream reach. A scour hole has developed at the location along the bend where the flow impacts the right abutment.

Debris accumulation on bridge at time of Level I or Level II site visit:

Date of insnortion

$$
6 / 5 / 96
$$

Level I

$6 / 5 / 96$

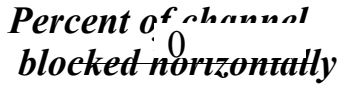

0
Percent of allonel
blocked verticatty

0

Level II

Moderate. Vines and dead trees were observed along the banks upstream.

Potential for debris

None were observed on 6/5/96.

Doscriho anv fonturos noar ar at tho hridoo that mav, affort flow, (includo ahsorvation dato) 


\section{Description of the Geomorphic Setting}

General topography The channel is located in a moderate relief valley setting with a narrow, slightly irregular flood plain and steep valley walls.

Geomorphic conditions at bridge site: downstream (DS), upstream (US)

Date of inspection $\quad 6 / 5 / 96$

DS left: $\quad$ Steep channel bank and a mildly sloped overbank.

DS right: $\quad$ Moderately sloped bank and mildly sloped flood plain.

US left: $\quad$ Moderately sloped bank and irregular overbank.

US right: $\quad$ Moderately sloped bank and mildly sloped flood plain.

\section{Description of the Channel}

\begin{tabular}{|c|c|c|c|}
\hline \multirow[b]{2}{*}{ Average top width } & 52 & \multirow[b]{2}{*}{ Average depth } & \multirow[b]{2}{*}{ Sand / Gravel } \\
\hline & $\stackrel{\boldsymbol{f t}}{\text { Gravel / Sand }}$ & & \\
\hline Predominant bed & & Bank material & Perennial and sinuous \\
\hline
\end{tabular}

with semi-alluvial channel boundaries and narrow point bars.

$6 / 5 / 96$

Vegetative ${ }^{2}{ }^{1}$ Brush with trees and grass on the overbank.

DS left: $\quad$ Brush and grass with grass on the flood plain.

DS right: $\quad$ Trees and brush

US left: $\quad$ Trees and brush with grass on the flood plain.

US right: $\quad$ No

Do banks appear stable? Slip failure of the downstream left bank material was observed on 6/5/ 96 on the opposite bank from a wide, gravel point bar in the downstream reach. There was also a
date of observatton. point bar in the upstream reach. The channel was sinuous near the site but becomes meandering further downstream.

None were observed on

6/5/96.

Describe any obstructions in channel and date of observation. 


\title{
Hydrology
}

Drainage area $\frac{16.6}{m_{i}{ }^{2}}$

Percentage of drainage area in physiographic provinces: (approximate)

Physiographic province/section New England/New England Upland
Percent of drainage area 100

\begin{abstract}
Is drainage area considered rural or urban? Rural Describe any significant urbanization:
\end{abstract}

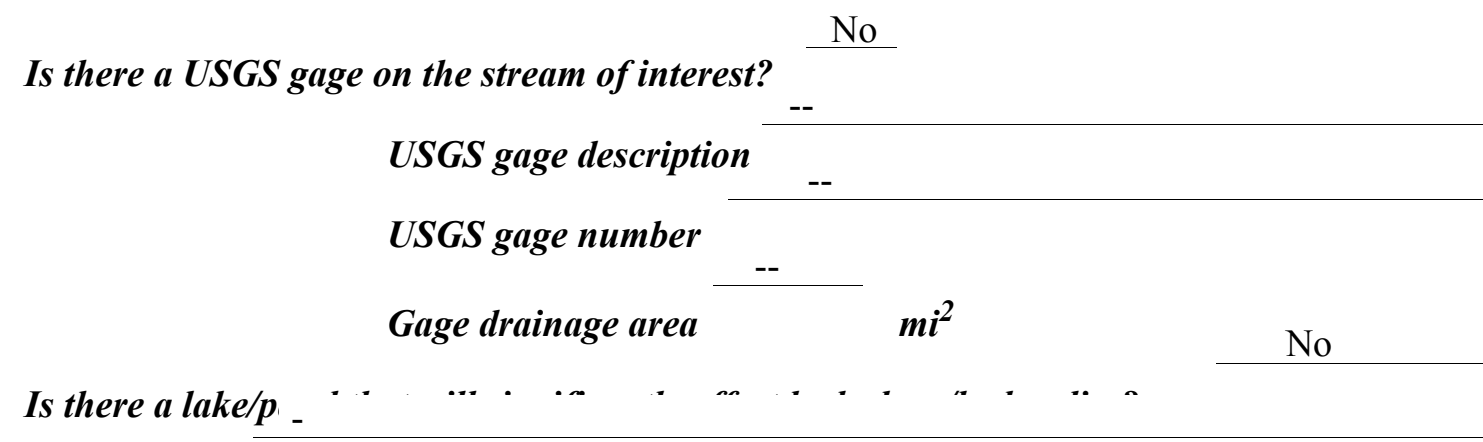

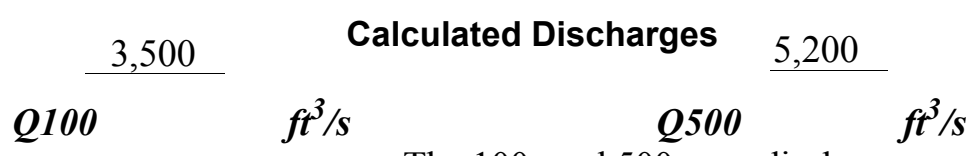

The 100- and 500-year discharges are the median

discharges from a range defined by flood frequency curves derived from several empirical methods (Benson, 1962; Johnson and Tasker, 1974; FHWA, 1983; Potter, 1957a\&b; Talbot, 1887). Each curve was extended graphically to the 500-year event. 


\section{Description of the Water-Surface Profile Model (WSPRO) Analysis}

Datum for WSPRO analysis (USGS survey, sea level, VTAOT plans) ～USGS survey

Datum tie between USGS survey and VTAOT plans None. Add 268.67 feet to the

USGS arbitrary survey datum to obtain the National Geodetic Vertical Datum of 1929.

Description of reference marks used to determine USGS datum. $\quad$ RM1 is a chiseled X on

top of the upstream end of the right abutment (elev. $504.47 \mathrm{ft}$, arbitrary survey datum). RM2 is a

nail 5 feet above the ground in a one foot diameter tree located on the left bank 25 feet upstream

of the left abutment (elev. $501.94 \mathrm{ft}$, arbitrary survey datum). BM1 (RM7, FEMA, 1991) is a

standard USGS tablet set in a bedrock outcrop about 140 feet upstream of the intersection of

Town Highway 37 (Churchill Road) and State Route 44 (elev. 510.32, arbitrary survey datum).

\section{Cross-Sections Used in WSPRO Analvsis}

\begin{tabular}{cccl}
\hline${ }^{1}$ Cross-section & $\begin{array}{c}\text { Section } \\
\text { Reference } \\
\text { Distance } \\
\text { (SRD) in feet }\end{array}$ & $\begin{array}{c}{ }^{2} \text { Cross-section } \\
\text { development }\end{array}$ & \multicolumn{1}{c}{ Comments } \\
\hline EXITX & -30 & 1 & Exit section \\
FULLV & 0 & 2 & $\begin{array}{l}\text { Downstream Full-valley sec- } \\
\text { tion (Templated from EXITX) }\end{array}$ \\
BRIDG & 0 & 1 & $\begin{array}{l}\text { Bridge section } \\
\text { Road Grade section } \\
\text { RDWAY }\end{array}$ \\
APTEM & 9 & 1 & $\begin{array}{l}\text { Approach section as } \\
\text { surveyed (Used as a } \\
\text { template) } \\
\text { APPRO }\end{array}$ \\
& 47 & 2 & $\begin{array}{l}\text { Modelled Approach } \\
\text { section (Templated from } \\
\text { APTEM) }\end{array}$ \\
\hline
\end{tabular}

${ }^{1}$ For location of cross-sections see plan-view sketch included with Level I field form, appendix E.

For more detail on how cross-sections were developed see WSPRO input file. 


\section{Data and Assumptions Used in WSPRO Model}

Hydraulic analyses of the reach were done by use of the Federal Highway Administration's WSPRO step-backwater computer program (Shearman and others, 1986, and Shearman, 1990). The analyses reported herein reflect conditions existing at the site at the time of the study. Furthermore, in the development of the model it was necessary to assume no accumulation of debris or ice at the site. Results of the hydraulic model are presented in the Bridge Hydraulic Summary, appendix B, and figure 7.

Channel roughness factors (Manning's " $n$ ") used in the hydraulic model were estimated using field inspections at each cross section following the general guidelines described by Arcement and Schneider (1989). Final adjustments to the values were made during the modelling of the reach. Channel " $\mathrm{n}$ " values for the reach ranged from 0.035 to 0.045 , and overbank " $n$ " values ranged from 0.040 to 0.060 .

Normal depth at the exit section (EXITX) was assumed as the starting water surface. This depth was computed by use of the slope-conveyance method outlined in the user's manual for WSPRO (Shearman, 1990). The slope used was $0.0029 \mathrm{ft} / \mathrm{ft}$, which was estimated from the 100 -year water surface profile downstream of this site documented in the flood insurance study for the Town of West Windsor (FEMA, 1991).

The surveyed approach section (APTEM) was moved along the approach channel slope $(0.0091 \mathrm{ft} / \mathrm{ft})$ to establish the modelled approach section (APPRO), one bridge length upstream of the upstream face as recommended by Shearman and others (1986). This location provides a consistent method for determining scour variables. 


\section{Bridge Hydraulics Summary}

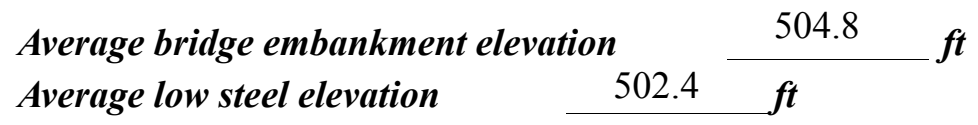

$$
\text { 100-year discharge } \quad 3,500 \quad \mathrm{ft}^{3} / \mathrm{s}
$$

Water-surface elevation in bridge opening $\quad 500.5 \mathrm{ft}$

Road overtopping? ___ Yes Discharge over road _ـ 2,340 $\boldsymbol{f t}^{3} / \mathrm{s}$

\begin{tabular}{llll} 
Area of flow in bridge opening & $250 \quad \boldsymbol{f t}^{2}$ \\
\cline { 2 - 3 } Average velocity in bridge opening & 4.7 & $\mathrm{ft} / \mathrm{s}$
\end{tabular}

Maximum WSPRO tube velocity at bridge $6.5 \mathrm{ft} / \mathrm{s}$

Water-surface elevation at Approach section with bridge 501.2

Water-surface elevation at Approach section without bridge $\quad 500.2$

Amount of backwater caused by bridge $\quad 1.0$ it

500-year discharge $\quad 5,200 \quad \mathrm{ft}^{3} / \mathrm{s}$

Water-surface elevation in bridge opening $\quad 501.0 \mathrm{ft}$

$\begin{array}{lllll}\text { Road overtopping? ___ Yes Discharge over road __ } & 4,120 & \mathrm{ft}^{3} / \mathrm{s}\end{array}$

Area of flow in bridge opening $\quad 264 \quad \mathrm{ft}^{2}$

Average velocity in bridge opening $4.1 \mathrm{ft} / \mathrm{s}$

Maximum WSPRO tube velocity at bridge 5.8 's

Water-surface elevation at Approach section with bridge 501.7

Water-surface elevation at Approach section without bridge $\quad 500.7$

Amount of backwater caused by bridge $\quad 1.0, t$

Incipient overtopping discharge $\quad 1,460 \mathrm{ft}^{3} / \mathrm{s}$

Water-surface elevation in bridge opening $498.7 \quad t$

Area of flow in bridge opening $196 \quad \mathrm{ft}^{2}$

Average velocity in bridge opening $\quad 7.4 \mathrm{ft} / \mathrm{s}$

Maximum WSPRO tube velocity at bridge $\quad 10.2 \mathrm{ft} / \mathrm{s}$

Water-surface elevation at Approach section with bridge

499.6

Water-surface elevation at Approach section without bridge

Amount of backwater caused by bridge $\quad 0.5$ it 


\section{Scour Analysis Summary}

\section{Special Conditions or Assumptions Made in Scour Analysis}

Scour depths were computed using the general guidelines described in Hydraulic Engineering Circular 18 (Richardson and Davis, 1995). Scour depths were calculated assuming an infinite depth of erosive material and a homogeneous particle-size distribution. The results of the scour analyses for the 100- and 500-year discharges are presented in tables 1 and 2 and the scour depths are shown graphically in figure 8 .

Contraction scour for all modeled discharges was computed by use of the Laursen clear-water contraction scour equation (Richardson and Davis, 1995, p. 32, equation 20). For contraction scour computations, the average depth in the contracted section $\left(\mathrm{Y}_{\mathrm{o}}\right)$ is subtracted from the depth of flow computed by the scour equation $\left(\mathrm{Y}_{2}\right)$ to determine the depth of scour. Variables for the Laursen clear-water scour equation include the discharge through the bridge opening, the median diameter of the bed material, and the bottom width of the bridge opening.

Abutment scour was computed by use of the Froehlich equation (Richardson and Davis, 1995, p. 48, equation 28). Variables for the Froehlich equation include the Froude number of the flow approaching the embankments, the length of the embankment blocking flow, and the depth of flow approaching the embankment less any roadway overtopping.

The length to depth ratio of the embankment blocking flow exceeded 25 for several modeled discharges at both abutments. Although the HIRE equation (Richardson and others, 1993 , p. 50 , equation 25) generally is applicable when this ratio exceeds 25 , the effective length of the embankment blocking flow at this site is questionable, particularly at the right abutment. Further, Hydraulic Engineering Circular 18 recommends that the field conditions be similar to those from which the HIRE equation was derived (Richardson and others, 1993). Therefore, the results from the HIRE equation were not used. 


\section{Scour Results}

Contraction scour:

Main channel

Live-bed scour

Clear-water scour

Depth to armoring

Left overbank

Right overbank

Local scour:

Abutment scour

Left abutment

Right abutment

Pier scour

Pier 1

Pier 2

Pier 3 100-year discharge
Incipient

500-year overtopping discharge discharge

(Scour depths in feet)

\begin{tabular}{|c|c|c|}
\hline -- & -- & -- \\
\hline 0.0 & 0.0 & 0.0 \\
\hline $0.0^{-}$ & $0.0^{-}$ & $0.9^{-}$ \\
\hline --- & -- $^{-}$ & --' \\
\hline--- & -- & -- \\
\hline
\end{tabular}

6.5

$15.7-$
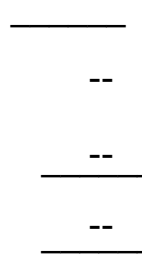

7.3

$17.7-$
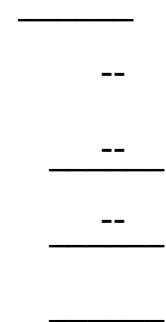

5.7

11.6-

\section{Riprap Sizing}

Abutments:

Left abutment

Right abutment

Piers:

Pier 1

Pier 2

\section{0-year discharge}

0.4

0.4
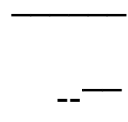

--
Incipient

500-year discharge ( $D_{50}$ in feet) 0.3

0.3
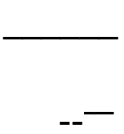

1.1

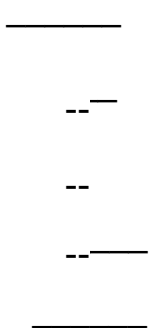

overtopping discharge

1.1 


$$
\begin{aligned}
& \hat{\theta}= \\
& =-
\end{aligned}
$$




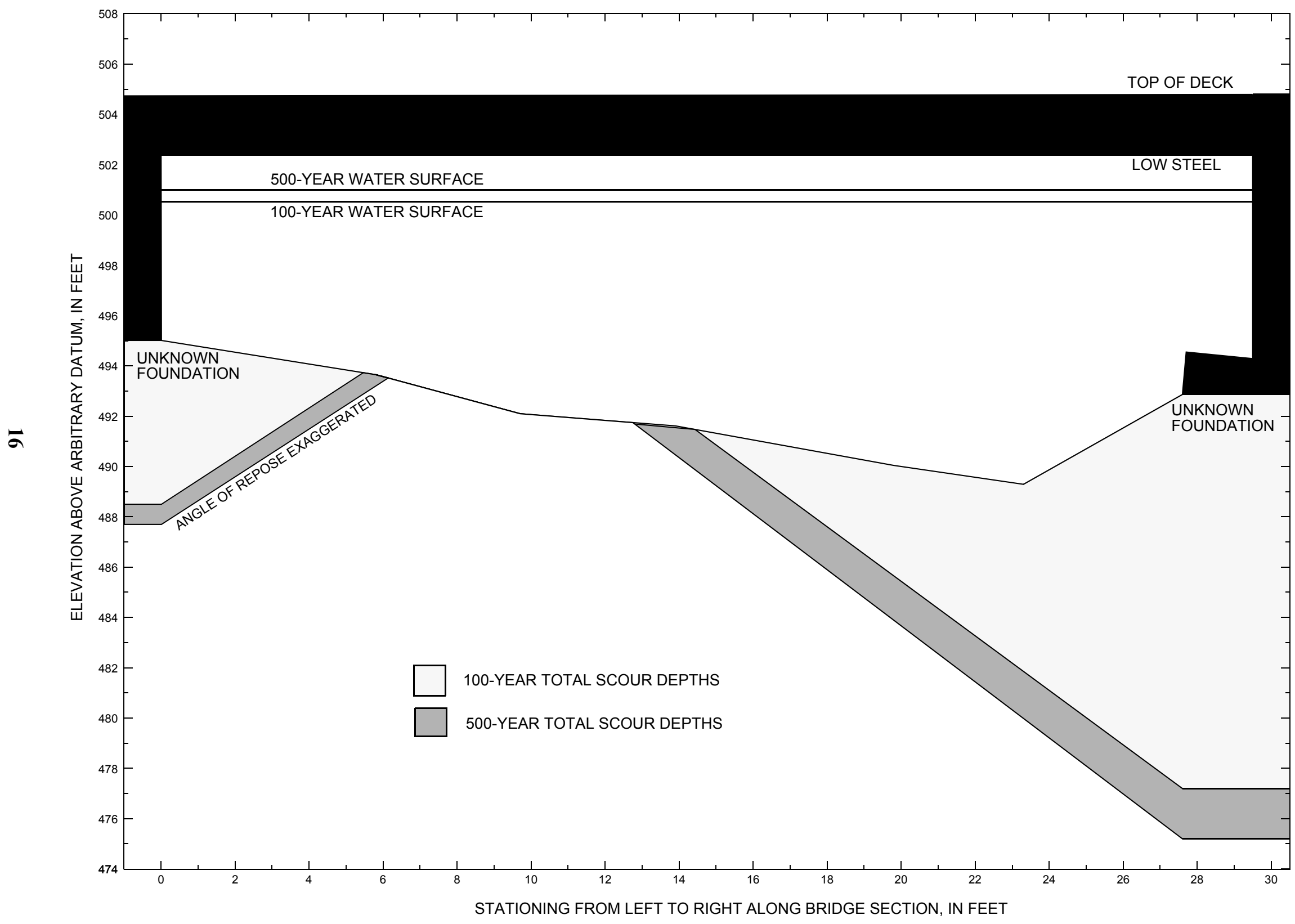

Figure 8. Scour elevations for the 100- and 500-year discharges at structure WWINTH00370034 on Town Highway 37, crossing Mill Brook, West Windsor, Vermont. 
Table 1. Remaining footing/pile depth at abutments for the 100-year discharge at structure WWINTH00370034 on Town Highway 37, crossing Mill Brook, West Windsor, Vermont.

[VTAOT, Vermont Agency of Transportation; --, no data]

\begin{tabular}{|c|c|c|c|c|c|c|c|c|c|c|c|}
\hline Description & Station $^{1}$ & $\begin{array}{l}\text { VTAOT } \\
\text { minimum } \\
\text { low-chord } \\
\text { elevation } \\
\text { (feet) }\end{array}$ & $\begin{array}{l}\text { Surveyed } \\
\text { minimum } \\
\text { low-chord } \\
\text { elevation } \\
\text { (feet) }\end{array}$ & $\begin{array}{c}\text { Bottom of } \\
\text { footing/pile } \\
\text { elevation }{ }^{2} \\
\text { (feet) }\end{array}$ & $\begin{array}{c}\text { Channel } \\
\text { elevation at } \\
\text { abutment/ } \\
\text { pier }^{2} \\
\text { (feet) }\end{array}$ & $\begin{array}{l}\text { Contraction } \\
\text { scour depth } \\
\text { (feet) }\end{array}$ & $\begin{array}{l}\text { Abutment } \\
\text { scour } \\
\text { depth } \\
\text { (feet) }\end{array}$ & $\begin{array}{l}\text { Pier } \\
\text { scour } \\
\text { depth } \\
\text { (feet) }\end{array}$ & $\begin{array}{l}\text { Depth of } \\
\text { total scour } \\
\text { (feet) }\end{array}$ & $\begin{array}{c}\text { Elevation of } \\
\text { scour }^{2} \\
\text { (feet) }\end{array}$ & $\begin{array}{c}\text { Remaining } \\
\text { footing/pile } \\
\text { depth } \\
\text { (feet) }\end{array}$ \\
\hline \multicolumn{12}{|c|}{100 -year discharge is 3,500 cubic-feet per second } \\
\hline Left abutment & 0.0 & -- & 502.4 & -- & 495.0 & 0.0 & 6.5 & -- & 6.5 & 488.5 & -- \\
\hline Right abutment & 29.6 & -- & 502.4 & -- & 492.9 & 0.0 & 15.7 & -- & 15.7 & 477.2 & -- \\
\hline
\end{tabular}

1.Measured along the face of the most constricting side of the bridge.

2.Arbitrary datum for this study.

Table 2. Remaining footing/pile depth at abutments for the 500-year discharge at structure WWINTH00370034 on Town Highway 37, crossing Mill Brook, West Windsor, Vermont.

[VTAOT, Vermont Agency of Transportation; --, no data]

\begin{tabular}{|c|c|c|c|c|c|c|c|c|c|c|c|}
\hline Description & Station $^{1}$ & $\begin{array}{l}\text { VTAOT } \\
\text { minimum } \\
\text { low-chord } \\
\text { elevation } \\
\text { (feet) }\end{array}$ & $\begin{array}{c}\text { Surveyed } \\
\text { minimum } \\
\text { low-chord } \\
\text { elevation } \\
\text { (feet) }\end{array}$ & $\begin{array}{c}\text { Bottom of } \\
\text { footing/pile } \\
\text { elevation } \\
\text { (feet) }\end{array}$ & $\begin{array}{c}\text { Channel } \\
\text { elevation at } \\
\text { abutment/ } \\
\text { pier }^{2} \\
\text { (feet) }\end{array}$ & $\begin{array}{l}\text { Contraction } \\
\text { scour depth } \\
\text { (feet) }\end{array}$ & $\begin{array}{c}\text { Abutment } \\
\text { scour } \\
\text { depth } \\
\text { (feet) }\end{array}$ & $\begin{array}{l}\text { Pier } \\
\text { scour } \\
\text { depth } \\
\text { (feet) }\end{array}$ & $\begin{array}{l}\text { Depth of } \\
\text { total scour } \\
\text { (feet) }\end{array}$ & $\begin{array}{c}\text { Elevation of } \\
\text { scour }^{2} \\
\text { (feet) }\end{array}$ & $\begin{array}{c}\text { Remaining } \\
\text { footing/pile } \\
\text { depth } \\
\text { (feet) }\end{array}$ \\
\hline \multicolumn{12}{|c|}{500 -year discharge is 5,200 cubic-feet per second } \\
\hline Left abutment & 0.0 & -- & 502.4 & -- & 495.0 & 0.0 & 7.3 & -- & 7.3 & 487.7 & -- \\
\hline Right abutment & 29.6 & -- & 502.4 & -- & 492.9 & 0.0 & 17.7 & -- & 17.7 & 475.2 & -- \\
\hline
\end{tabular}

1.Measured along the face of the most constricting side of the bridge.

2.Arbitrary datum for this study. 


\section{SELECTED REFERENCES}

Arcement, G.J., Jr., and Schneider, V.R., 1989, Guide for selecting Manning's roughness coefficients for natural channels and flood plains:

U.S. Geological Survey Water-Supply Paper 2339, 38 p.

Barnes, H.H., Jr., 1967, Roughness characteristics of natural channels: U.S. Geological Survey Water-Supply Paper 1849,213 p.

Benson, M. A., 1962, Factors Influencing the Occurrence of Floods in a Humid Region of Diverse Terrain: U.S. Geological Survey WaterSupply Paper 1580-B, 64 p.

Brown, S.A. and Clyde, E.S., 1989, Design of riprap revetment: Federal Highway Administration Hydraulic Engineering Circular No. 11, Publication FHWA-IP-89-016, 156 p.

Federal Emergency Management Agency, 1991, Flood Insurance Study, Town of West Windsor, Windsor County, Vermont: Washington, D.C., June 1991.

Federal Highway Administration, 1983, Runoff estimates for small watersheds and development of sound design: Federal Highway Administration Report FHWA-RD-77-158.

Federal Highway Administration, 1993, Stream Stability and Scour at Highway Bridges: Participant Workbook: Federal Highway Administration Report FHWA-HI-91-011.

Froehlich, D.C., 1989, Local scour at bridge abutments in Ports, M.A., ed., Hydraulic Engineering--Proceedings of the 1989 National Conference on Hydraulic Engineering: New York, American Society of Civil Engineers, p. 13-18.

Hayes, D.C.,1993, Site selection and collection of bridge-scour data in Delaware, Maryland, and Virginia: U.S. Geological Survey WaterResources Investigation Report 93-4017, 23 p.

Interagency Advisory Committee on Water Data, 1982, Guidelines for determining flood flow frequency: U.S. Geological Survey, Bulletin 17B of the Hydrology Subcommittee, 190 p.

Johnson, C.G. and Tasker, G.D.,1974, Progress report on flood magnitude and frequency of Vermont streams: U.S. Geological Survey OpenFile Report 74-130, 37 p.

Lagasse, P.F., Schall, J.D., Johnson, F., Richardson, E.V., Chang, F., 1995, Stream Stability at Highway Structures: Federal Highway Administration Hydraulic Engineering Circular No. 20, Publication FHWA-IP-90-014, 144 p.

Laursen, E.M., 1960, Scour at bridge crossings: Journal of the Hydraulics Division, American Society of Civil Engineers, v. 86, no. HY2, p. 39-53.

Potter, W. D., 1957a, Peak rates of runoff in the Adirondack, White Mountains, and Maine woods area, Bureau of Public Roads

Potter, W. D., 1957b, Peak rates of runoff in the New England Hill and Lowland area, Bureau of Public Roads

Richardson, E.V. and Davis, S.R., 1995, Evaluating scour at bridges: Federal Highway Administration Hydraulic Engineering Circular No. 18, Publication FHWA-IP-90-017, 204 p.

Richardson, E.V., Simons, D.B., and Julien, P.Y., 1990, Highways in the river environment: Federal Highway Administration Publication FHWA-HI-90-016.

Ritter, D.F., 1984, Process Geomorphology: W.C. Brown Co., Debuque, Iowa, 603 p.

Shearman, J.O., 1990, User's manual for WSPRO--a computer model for water surface profile computations: Federal Highway Administration Publication FHWA-IP-89-027, 187 p.

Shearman, J.O., Kirby, W.H., Schneider, V.R., and Flippo, H.N., 1986, Bridge waterways analysis model; research report: Federal Highway Administration Publication FHWA-RD-86-108, 112 p.

Talbot, A.N., 1887, The determination of water-way for bridges and culverts.

U.S. Geological Survey, 1972, Cavendish, Vermont 7.5 Minute Series quadrangle map: U.S. Geological Survey Topographic Maps, Photoinspected 1983, Contour Interval, 20 feet, Scale 1:24,000. 


\section{APPENDIX A: \\ WSPRO INPUT FILE}




\section{WSPRO INPUT FILE}

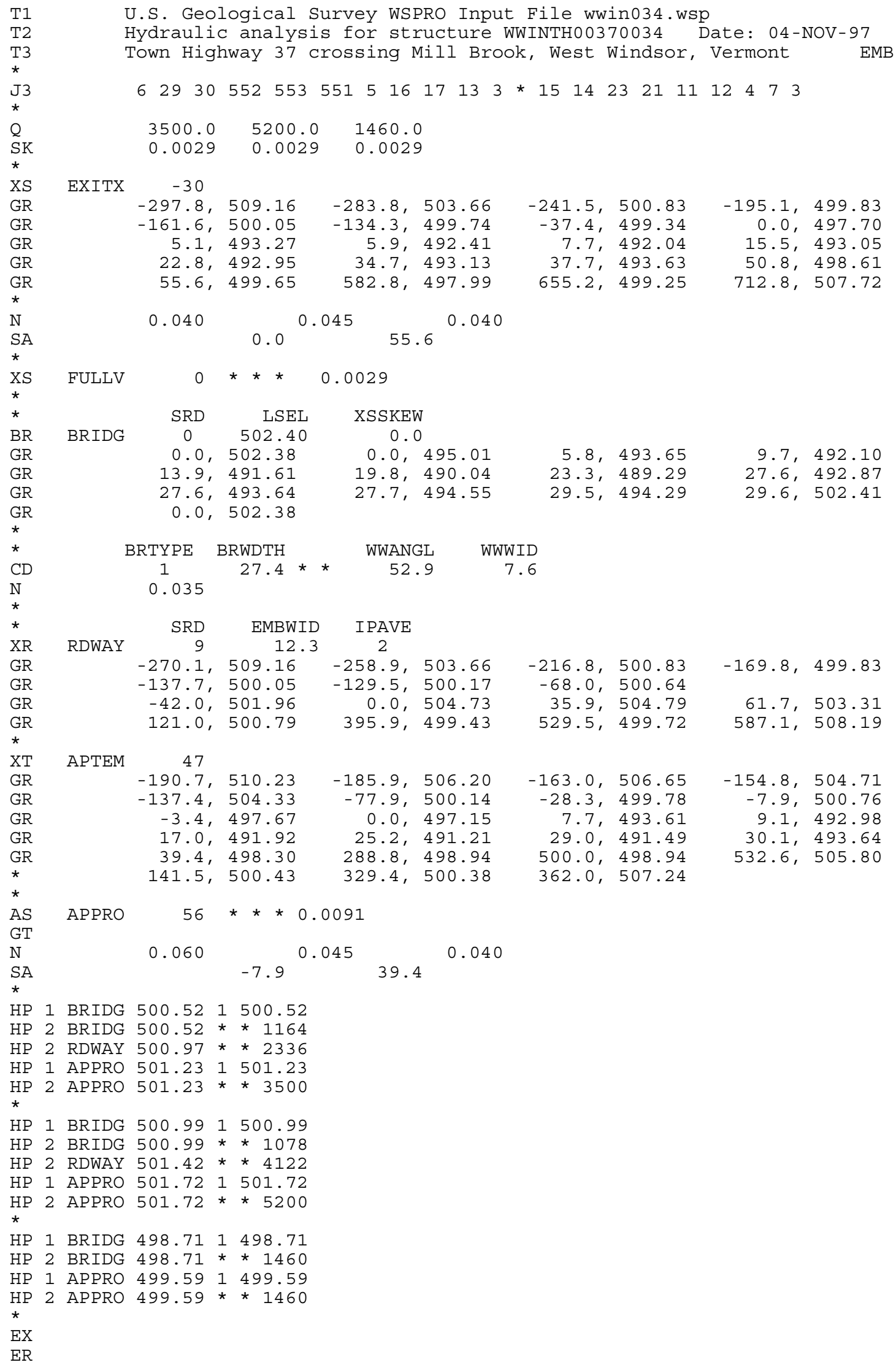




\section{APPENDIX B: \\ WSPRO OUTPUT FILE}




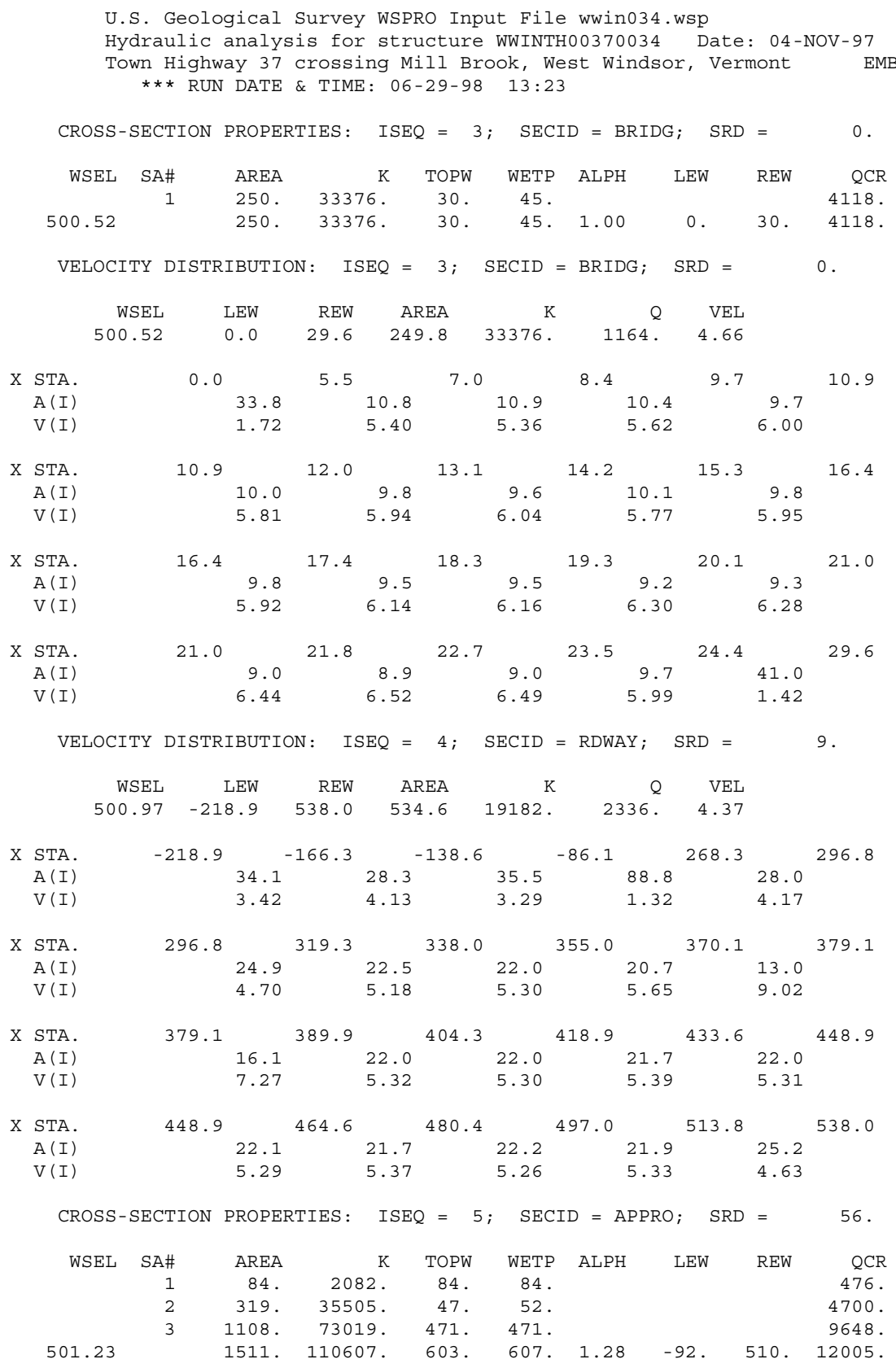

VELOCITY DISTRIBUTION: ISEQ $=5 ;$ SECID $=$ APPRO; $\quad$ SRD $=56$.

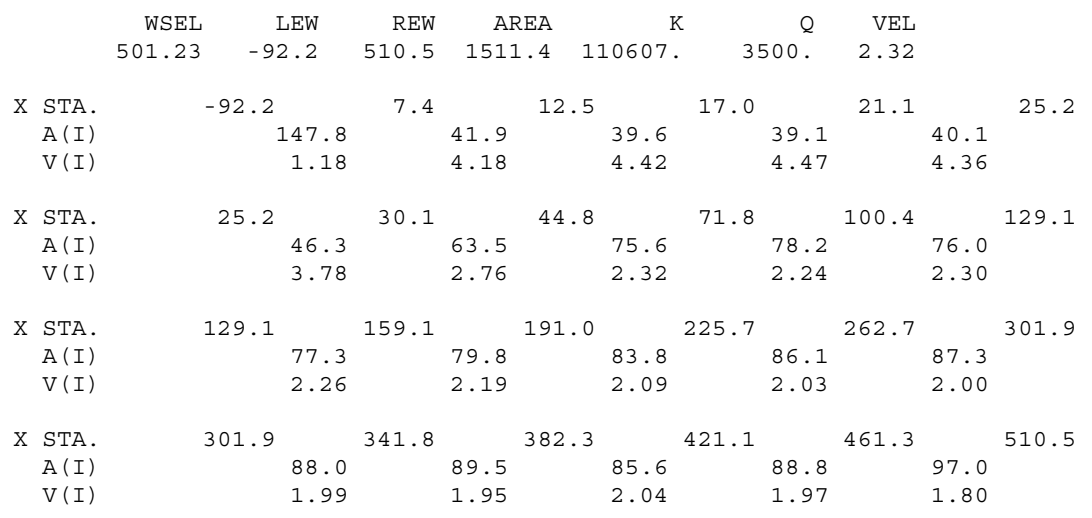


WSPRO FEDERAL HIGHWAY ADMINISTRATION - U. S. GEOLOGICAL SURVEY

V060188 MODEL FOR WATER-SURFACE PROFILE COMPUTATIONS

U.S. Geological Survey WSPRO Input File wwin034.wsp

Hydraulic analysis for structure WWINTH00370034 Date: 04-NOV-97

Town Highway 37 crossing Mill Brook, West Windsor, Vermont EMB *** RUN DATE \& TIME: 06-29-98 13:23

CROSS-SECTION PROPERTIES: $\quad$ ISEQ $=3 ;$ SECID $=$ BRIDG $; \quad$ SRD $=0$.

\begin{tabular}{|c|c|c|c|c|c|c|c|c|c|}
\hline WSEL & SA\# & AREA & $\mathrm{K}$ & TOPW & WETP & ALPH & LEW & REW & QCR \\
\hline & 1 & 264. & 36029 . & 30. & 46. & & & & 4467 . \\
\hline 500.99 & & 264 . & 36029 . & 30. & 46. & 1.00 & 0 . & 30. & 4467. \\
\hline
\end{tabular}

VELOCITY DISTRIBUTION: ISEQ $=3 ; \quad$ SECID $=$ BRIDG; $\quad$ SRD $=0$.

\begin{tabular}{|c|c|c|c|c|c|c|c|c|c|c|c|}
\hline & & SEL & LEW & REW & AR & EA & K & Q & VEL & & \\
\hline & 500 & .99 & 0.0 & 29.6 & 263 & .7 & 36029. & 1078. & 4.09 & & \\
\hline $\mathrm{x}$ & STA. & 0.0 & & 5.5 & & 7.0 & & 8.4 & 9.6 & & 10.8 \\
\hline & $A(I)$ & & 36.2 & & 11.4 & & 11.1 & 10.9 & & 10.2 & \\
\hline & $V(I)$ & & 1.49 & & 4.72 & & 4.84 & 4.95 & & 5.28 & \\
\hline $\mathrm{x}$ & STA. & 10.8 & & 11.9 & & 13.0 & & 14.1 & 15.2 & & 16.3 \\
\hline & $A(I)$ & & 10.3 & & 10.4 & & 10.4 & 10.2 & & 10.5 & \\
\hline & $\mathrm{V}(\mathrm{I})$ & & 5.22 & & 5.21 & & 5.18 & 5.30 & & 5.15 & \\
\hline $\mathrm{X}$ & STA. & 16.3 & & 17.3 & & 18.2 & & 19.2 & 20.1 & & 20.9 \\
\hline & $A(I)$ & & 10.4 & & 10.0 & & 10.0 & 9.7 & & 9.5 & \\
\hline & $V(I)$ & & 5.20 & & 5.39 & & 5.41 & 5.54 & & 5.67 & \\
\hline $\mathrm{X}$ & STA. & 20.9 & & 21.8 & & 22.6 & & 23.4 & 24.3 & & 29.6 \\
\hline & $A(I)$ & & 9.5 & & 9.3 & & 9.4 & 10.2 & & 44.1 & \\
\hline & $V(I)$ & & 5.70 & & 5.77 & & 5.74 & 5.26 & & 1.22 & \\
\hline & VELOCI & TY DISTR & RIBUTIO & ON : & $\mathrm{SEQ}=$ & $4 ;$ & SECID = & RDWAY ; & $\mathrm{SRD}=$ & & 9. \\
\hline & & SEL & LEW & REW & $\mathrm{AR}$ & EA & K & $Q$ & VEL & & \\
\hline & 501 & .42 & 25.6 & 541.1 & 801 & .6 & 36252 . & 4122 . & 5.14 & & \\
\hline $\mathrm{X}$ & STA. & -225.6 & & -171.4 & & 145.8 & & 10.7 & 171.7 & & 228.3 \\
\hline & $A(I)$ & & 51.4 & & 38.7 & & 44.2 & 89.3 & & 57.8 & \\
\hline & $V(I)$ & & 4.01 & & 5.33 & & 4.67 & 2.31 & & 3.57 & \\
\hline $\mathrm{X}$ & STA. & 228.3 & & 264.3 & & 292.6 & & 16.6 & 338.1 & & 352.8 \\
\hline & $A(I)$ & & 45.0 & & 39.9 & & 36.9 & 35.5 & & 25.6 & \\
\hline & $V(I)$ & & 4.58 & & 5.16 & & 5.59 & 5.81 & & 8.06 & \\
\hline $\mathrm{X}$ & STA. & 352.8 & & 368.1 & & 386.5 & & 03.6 & 420.5 & & 438.2 \\
\hline & $A(I)$ & & 27.7 & & 35.0 & & 33.7 & 33.1 & & 33.9 & \\
\hline & $V(I)$ & & 7.43 & & 5.89 & & 6.12 & 6.23 & & 6.08 & \\
\hline $\mathrm{x}$ & STA. & 438.2 & & 455.9 & & 473.9 & & 93.0 & 512.4 & & 541.1 \\
\hline & $A(I)$ & & 33.3 & & 33.1 & & 34.5 & 34.0 & & 39.3 & \\
\hline & $V(I)$ & & 6.19 & & 6.23 & & 5.97 & 6.07 & & 5.25 & \\
\hline & CROSS - & SECTION & PROPER & RTIES: & ISEQ & $=5 ;$ & SECID & $\mathrm{D}=\mathrm{APPRO} ;$ & SRD & $=$ & 56. \\
\hline & WSEL & SA\# & AREA & & K & TOPW & WETP & $\mathrm{ALPH}$ & LEW & REW & QCR \\
\hline & & 1 & 127 & 393 & & 91. & 91. & & & & 851. \\
\hline & & 2 & 342 . & 3990 & & 47. & 52. & & & & 5221. \\
\hline & & 3 & 1340 . & 9981 & & 473. & 474 . & & & & 12790 . \\
\hline & 501.72 & & 1809. & 14366 & & 612. & 617. & 1.22 & 99. & 513. & 16011. \\
\hline
\end{tabular}

VELOCITY DISTRIBUTION: ISEQ $=5 ;$ SECID $=$ APPRO $; \quad$ SRD $=56$.

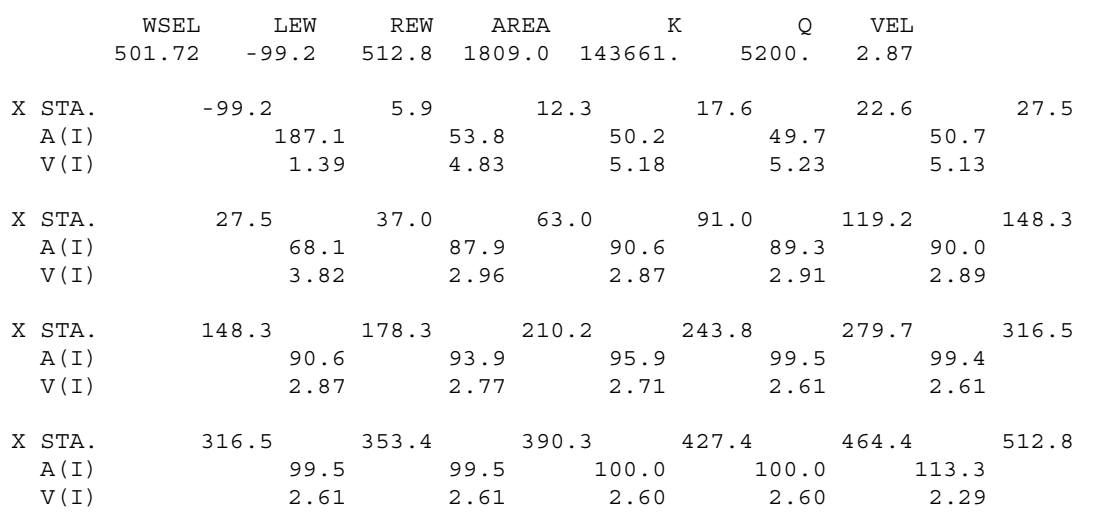


WSPRO OUTPUT FILE (continued)

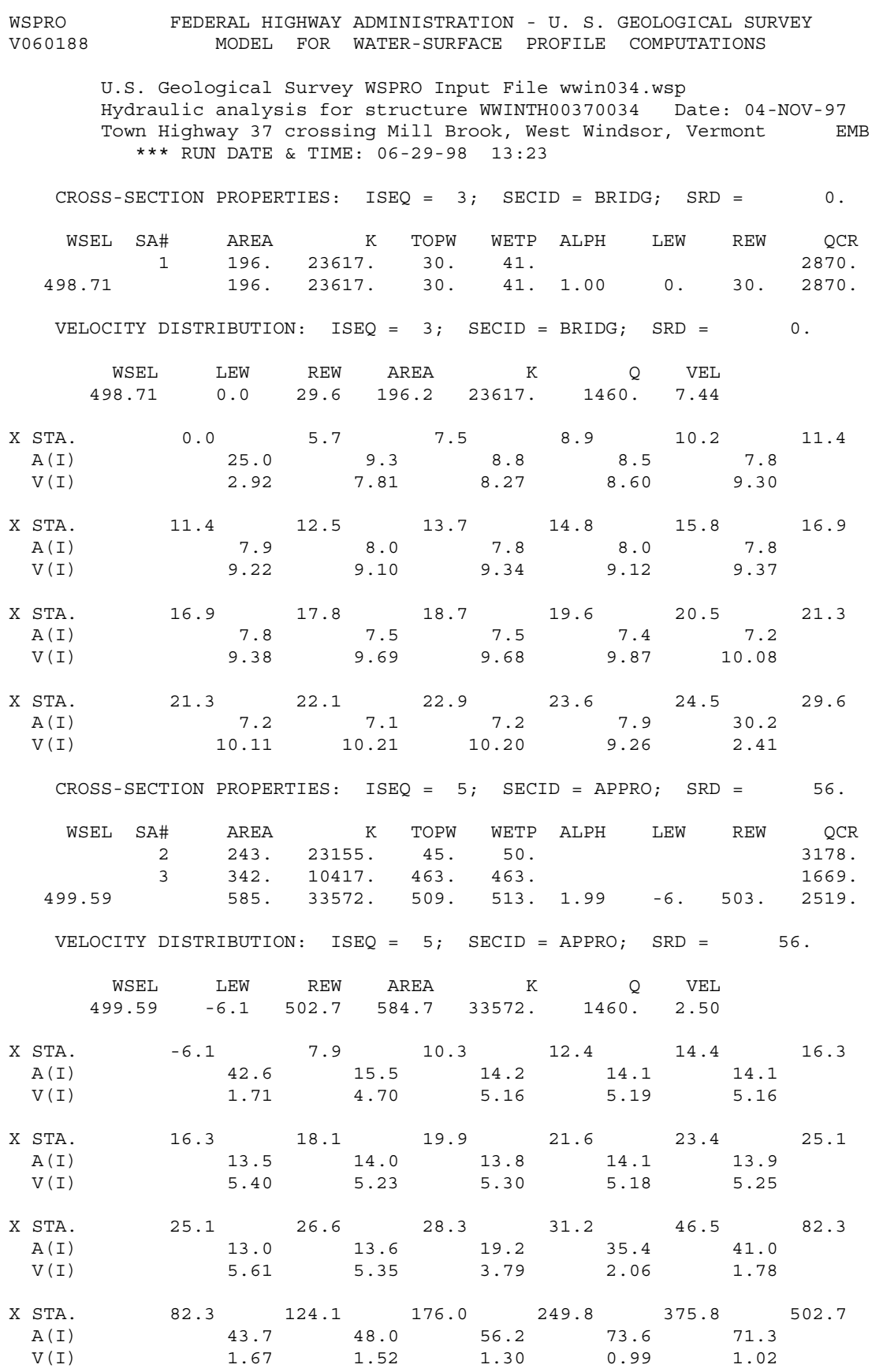


WSPRO OUTPUT FILE (continued)

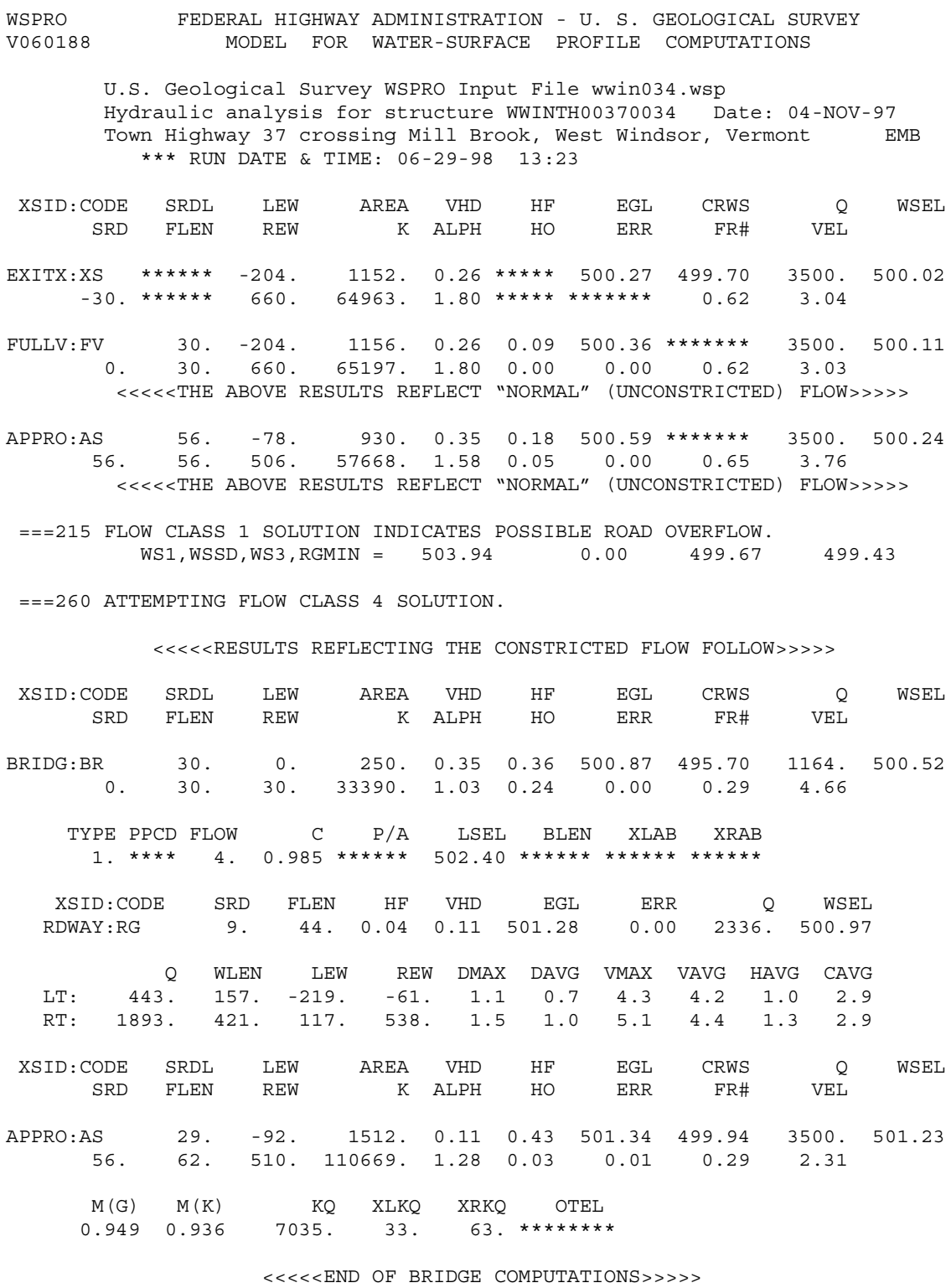

FIRST USER DEFINED TABLE.

\begin{tabular}{|c|c|c|c|c|c|c|c|c|}
\hline XSID : CODE & SRD & LEW & REW & Q & K & AREA & VEL & WSEL \\
\hline EXITX:XS & -30. & -204 . & 660. & 3500. & 64963 . & 1152 . & 3.04 & 500.02 \\
\hline FULLV : FV & 0 . & -204 . & 660. & 3500 . & 65197. & 1156. & 3.03 & 500.11 \\
\hline BRIDG : BR & 0 . & 0 . & 30. & 1164. & 33390 . & 250 . & 4.66 & 500.52 \\
\hline RDWAY : RG & 9. * & $\star * \star * *$ & 443. & 2336 . & $\star * \star * \star * \star *$ & $\approx * \star * * *$ & 2.00 & 500.97 \\
\hline APPRO: AS & 56. & -92. & 510. & 3500 . & 110669. & 1512. & 2.31 & 501.23 \\
\hline XSID : CODE & XLKQ & XRKQ & & & & & & \\
\hline APPRO:AS & 33. & 63. & 035 & & & & & \\
\hline
\end{tabular}

SECOND USER DEFINED TABLE.

$\begin{array}{lcrrrrrrrr}\text { XSID : CODE } & \text { CRWS } & \text { FR\# } & \text { YMIN } & \text { YMAX } & \text { HF } & \text { HO } & \text { VHD } & \text { EGL } & \text { WSEL } \\ \text { EXITX:XS } & 499.70 & 0.62 & 492.04 & 509.16 * * * * * * * * * * & 0.26 & 500.27 & 500.02 \\ \text { FULLV:FV } & * * * * * * * * & 0.62 & 492.13 & 509.25 & 0.09 & 0.00 & 0.26 & 500.36 & 500.11 \\ \text { BRIDG:BR } & 495.70 & 0.29 & 489.29 & 502.41 & 0.36 & 0.24 & 0.35 & 500.87 & 500.52 \\ \text { RDWAY:RG } & * * * * * * * * * * * * * * * & 499.43 & 509.16 & 0.04 * * * * * * & 0.11 & 501.28 & 500.97 \\ \text { APPRO:AS } & 499.94 & 0.29 & 491.29 & 510.31 & 0.43 & 0.03 & 0.11 & 501.34 & 501.23\end{array}$


WSPRO OUTPUT FILE (continued)

WSPRO FEDERAL HIGHWAY ADMINISTRATION - U. S. GEOLOGICAL SURVEY

V060188 MODEL FOR WATER-SURFACE PROFILE COMPUTATIONS

U.S. Geological Survey WSPRO Input File wwin034.wsp

Hydraulic analysis for structure WWINTH00370034 Date: 04-NOV-97

Town Highway 37 crossing Mill Brook, West Windsor, Vermont EMB *** RUN DATE \& TIME: 06-29-98 13:23

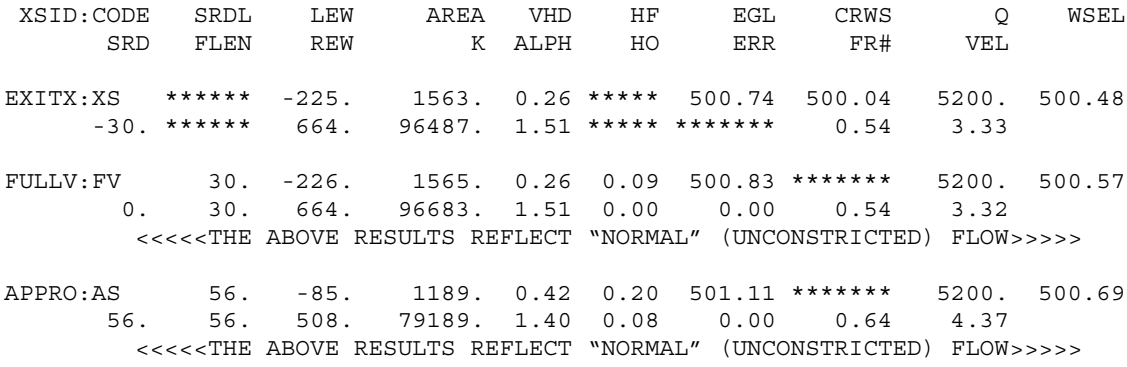

\begin{tabular}{|c|c|c|c|c|c|c|c|c|}
\hline XSID: CODE & SRD & LEW & REW & $Q$ & K & AREA & VEL & WSEL \\
\hline EXITX:XS & -30 & -225. & 664. & 5200. & 96487. & 1563. & 3.33 & 500.48 \\
\hline FULLV : FV & 0. & -226 & 664. & 5200 . & 96683. & 1565. & 3.32 & 500.57 \\
\hline BRIDG : BR & 0 . & 0 . & 30. & 1078. & 36012 . & 264 . & 4.09 & 500.99 \\
\hline RDWAY : RG & 9. * & $* * \star * *$ & 895. & 4122. & 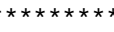 & $* * * * *$ & 2.00 & 501.42 \\
\hline APPRO: AS & 56. & -99. & 513. & 5200. & 143975. & 1812. & 2.87 & 501.72 \\
\hline XSID : CODE & XLKQ & XRKQ & & & & & & \\
\hline APPRO : AS & 79. & 109. & $773^{\circ}$ & & & & & \\
\hline
\end{tabular}

SECOND USER DEFINED TABLE.

$\begin{array}{lcrrrrrrrr}\text { XSID : CODE } & \text { CRWS } & \text { FR\# } & \text { YMIN } & \text { YMAX } & \text { HF } & \text { HO } & \text { VHD } & \text { EGL } & \text { WSEL } \\ \text { EXITX:XS } & 500.04 & 0.54 & 492.04 & 509.16 * * * * * * * * * * & 0.26 & 500.74 & 500.48 \\ \text { FULLV : FV } & * * * * * * * * & 0.54 & 492.13 & 509.25 & 0.09 & 0.00 & 0.26 & 500.83 & 500.57 \\ \text { BRIDG :BR } & 495.53 & 0.25 & 489.29 & 502.41 & 0.40 & 0.12 & 0.27 & 501.26 & 500.99 \\ \text { RDWAY : RG } & * * * * * * * * * * * * * * * * & 499.43 & 509.16 & 0.06 * * * * * * & 0.16 & 501.82 & 501.42 \\ \text { APPRO:AS } & 500.32 & 0.32 & 491.29 & 510.31 & 0.59 & 0.02 & 0.16 & 501.88 & 501.72\end{array}$


WSPRO OUTPUT FILE (continued)

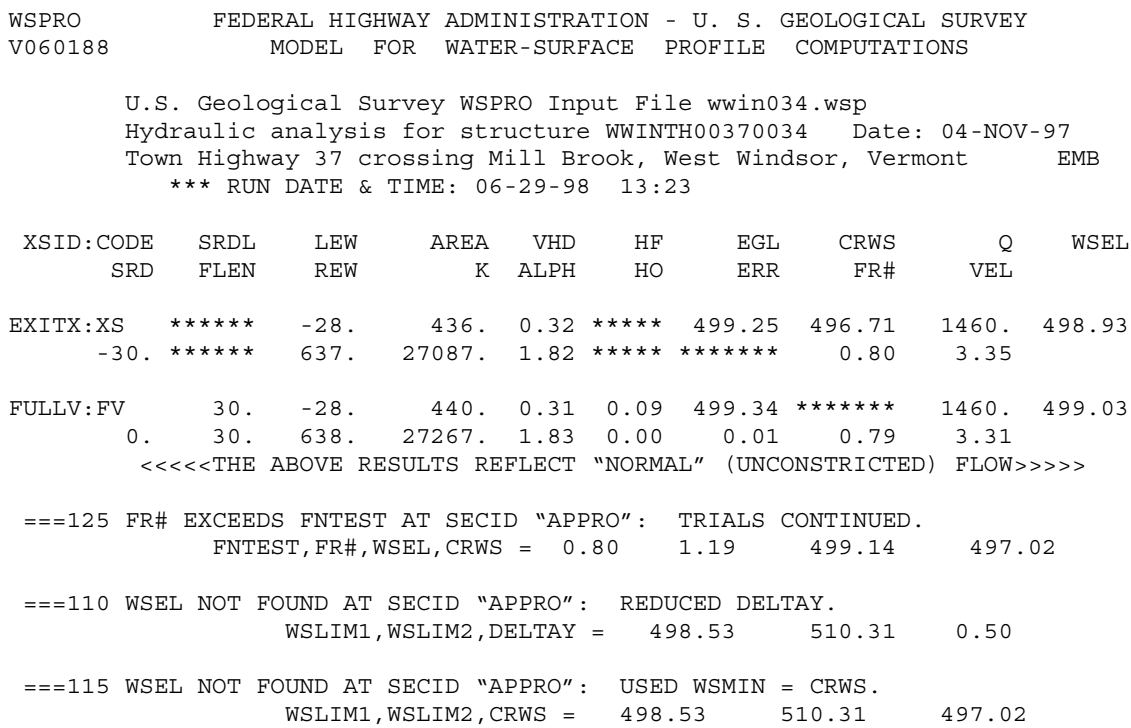

\begin{tabular}{|c|c|c|c|c|c|c|c|c|}
\hline XSID : CODE & SRD & LEW & REW & $Q$ & K & AREA & VEL & WSEL \\
\hline EXITX:XS & -30. & -28 & 637. & 1460 . & 27087 & 436. & 3.35 & 498.93 \\
\hline FULLV : FV & 0 . & -28 & 638. & 1460. & 27267 . & 440. & 3.31 & 499.03 \\
\hline BRIDG : BR & 0 . & 0 . & 30. & 1460. & 23624 . & 196. & 7.44 & 498.71 \\
\hline RDWAY : RG & \multicolumn{3}{|c|}{ 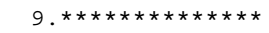 } & 0 . & 0 . & 0 . & \multicolumn{2}{|c|}{$2.00 * \star \star \star \star * \star * \star *$} \\
\hline APPRO : AS & 56. & -6 . & 503. & 1460 . & 33571 . & 585. & 2.50 & 499.59 \\
\hline XSID : CODE & XLKQ & $\mathrm{XRKQ}$ & \multicolumn{2}{|c|}{$\mathrm{KQ}$} & & & & \\
\hline APPRO: AS & 4. & 34. & \multicolumn{3}{|c|}{23260 . } & & & \\
\hline
\end{tabular}

SECOND USER DEFINED TABLE.

\begin{tabular}{|c|c|c|c|c|c|c|c|c|c|}
\hline 2 & CRWS & FR\# & $\mathrm{YM}$ & YMAX & $\mathrm{HF}$ & $\mathrm{HO}$ & VHD & EGL & \\
\hline XITX:XS & 496.71 & .80 & 92.04 & 09.16 * & & $* *$ & 0.32 & 99.25 & \\
\hline UL & $\star \star \star \star \star \star \star *$ & & 273 & 9.25 & 0.09 & 0.00 & 1 & 34 & \\
\hline & .31 & 1 & & & & 0.22 & 6 & 57 & 498 \\
\hline & $* * *$ & $* * * *$ & & & 0. & 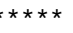 & .20 & 69 * & \\
\hline תות & 497.02 & 0.58 & 91.29 & 10.31 & 0.11 & 0.10 & 0.19 & 499.78 & \\
\hline
\end{tabular}




\section{APPENDIX C:}

\section{BED-MATERIAL PARTICLE-SIZE DISTRIBUTION}




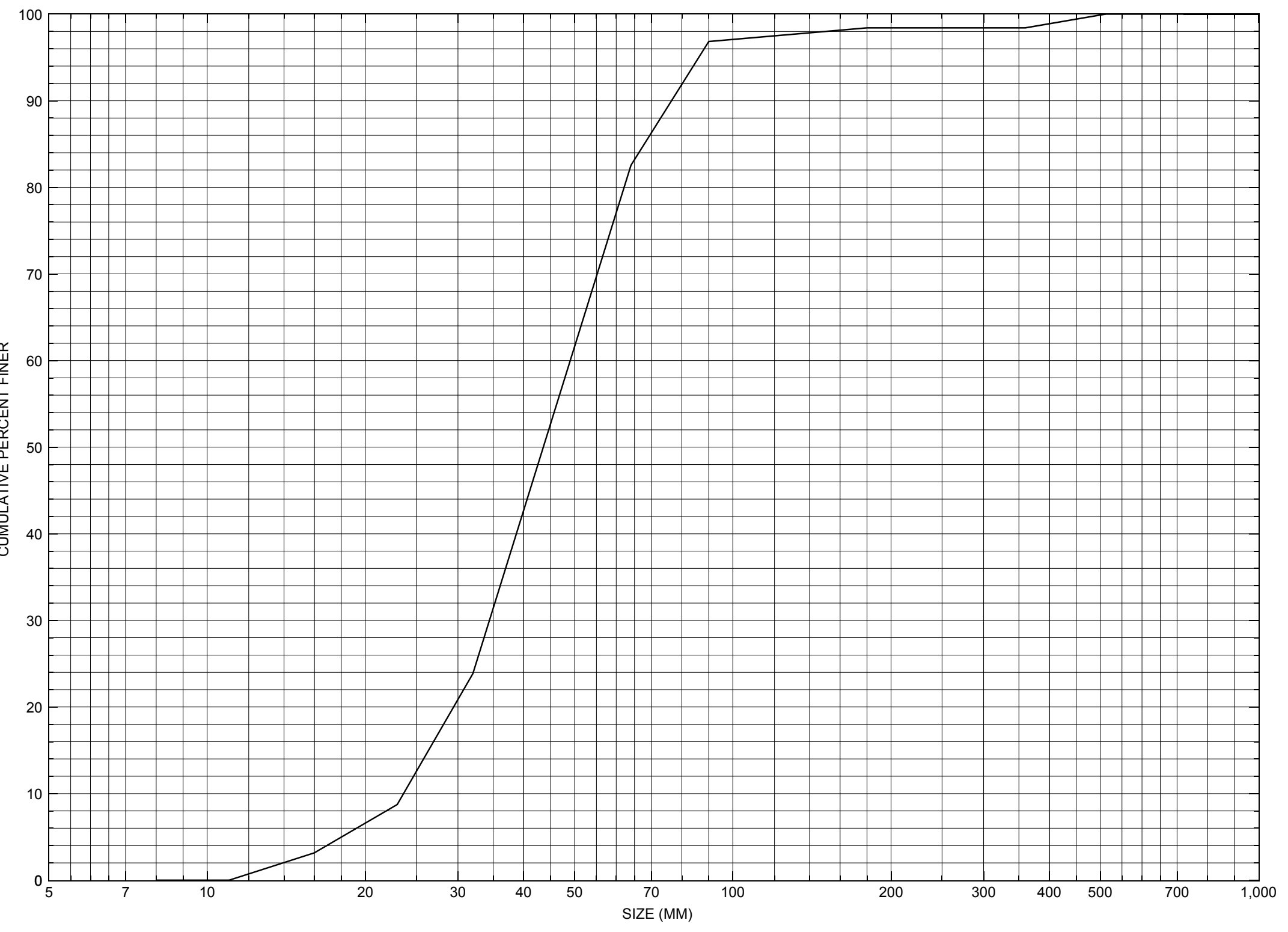

Appendix C. Bed material particle-size distribution for a pebble count in the channel approach of structure WWINTH00370034, in West Windsor, Vermont. 


\section{APPENDIX D: \\ HISTORICAL DATA FORM}




\section{Structure Number WWINTH00370034}

\section{General Location Descriptive}

Data collected by (First Initial, Full last name) $\mathbf{E}$. BOEHMLER

Date $(M M / D D / Y Y) \_\mathbf{0 3} / \underline{23} / \underline{95}$

Highway District Number (I - 2; nn) $\mathbf{0 4}$

Town (FIPS place code; I - 4; nnnnn) $\mathbf{8 3 0 5 0}$

Waterway (I - 6) MILL BROOK

Route Number $\underline{\text { TH037 }}$

Topographic Map Cavendish

Latitude (I - 16; nnnn.n) $\mathbf{4 3 2 7 7}$
County (FIPS county code; I - 3; nnn)

Mile marker (I - 11; nnn.nnn) $\mathbf{0 0 0 0 0 0}$

Road Name (I - 7): -

Vicinity (I - 9) 0.06 MI TO JCT W VT44

Hydrologic Unit Code: $\mathbf{0 1 0 8 0 1 0 4}$

Longitude (i - 17; nnnnn.n) $\mathbf{7 2 2 9 3}$

\section{Select Federal Inventory Codes}

FHWA Structure Number (I - 8) $\mathbf{1 0 1 4 2 2 0 0 3 4 1 4 2 2}$

Maintenance responsibility $(I-21 ; n n) \quad \mathbf{0 3}$

Year built (I - 27; YYYY) 1890

Average daily traffic, ADT (I - 29; nnnnnn) 000050

Year of ADT (I - 30; YY) $\mathbf{9 1}$

Opening skew to Roadway $(I-34 ; n n) \quad \mathbf{0 0}$

Operational status $(I-41 ; X) \quad \mathbf{P}$

Structure type (I - 43; nnn) $\mathbf{7 1 2}$

Approach span structure type (I - 44; nnn) $\mathbf{0 0 0}$

Number of spans (I - 45; nnn) $\mathbf{0 0 1}$

Number of approach spans (I - 46; nnnn) $\mathbf{0 0 0 0}$

Comments:

The structural inspection report of $11 / 1 / 93$ indicates the structure is a creosote treated timber, thru-truss type covered bridge. The abutments are constructed of "laid-up" stone walls with concrete facing, while the four wingwalls are "laid-up" stone. The concrete reportedly is in "like new" condition. The foundation type recorded for the abutments is an unknown foundation. Hence, the report indicates no footing exposure or undermining is evident. The abutment walls are protected well with riprap. The report mentions that no problems with channel scour, bank erosion, or debris accumulation are evident. The waterway makes a moderate bend into the crossing. The streambed material is (Continued, page 33) 


\section{Bridge Hydrologic Data}

Is there hydrologic data available? $\underline{\mathbf{N}}$ if No, type ctrl-n $h \quad$ VTAOT Drainage area $\left(m i^{2}\right)$ : -

Terrain character:

Stream character \& type: -

Streambed material:

Discharge Data (cfs):

$$
\begin{aligned}
& Q_{2.33}- \\
& Q_{50}-
\end{aligned}
$$

Record flood date $(M M / D D / Y Y)$ :

Estimated Discharge (cfs): Ice conditions (Heavy, Moderate, Light) : -

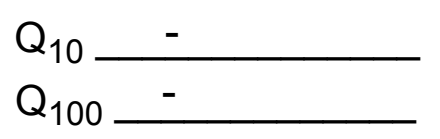

$$
\begin{aligned}
& Q_{25}- \\
& Q_{500}-
\end{aligned}
$$

Water surface elevation $(f t):-$

The stage increases to maximum highwater elevation (Rapidly, Not rapidly):

The stream response is (Flashy, Not flashy):

Describe any significant site conditions upstream or downstream that may influence the stream's stage: -

Watershed storage area (in percent): _ _ \%

The watershed storage area is: - (1-mainly at the headwaters; 2- uniformly distributed; 3-immediatly upstream oi the site)

Water Surface Elevation Estimates for Existing Structure:

\begin{tabular}{|l|l|l|l|l|l|}
\hline Peak discharge frequency & $Q_{2.33}$ & $Q_{10}$ & $Q_{25}$ & $Q_{50}$ & $Q_{100}$ \\
Water surface elevation (ft)) & - & - & - & - & - \\
Velocity (ft/sec) & - & - & - & - & - \\
\hline
\end{tabular}

Long term stream bed changes: -

Is the roadway overtopped below the $\mathrm{Q}_{100}$ ? (Yes, No, Unknown): $\mathbf{U}$ Frequency: Relief Elevation (ft): Discharge over roadway at $Q_{100}\left(f^{3} / \mathrm{sec}\right)$ :

Are there other structures nearby? (Yes, No, Unknown): $\underline{\mathbf{U}}$ Upstream distance (miles): Town: If No or Unknown, type ctrl-n os Highway No. : Structure No. : Year Built:

Clear span (ft): Clear Height $(f t)$ : Full Waterway $\left(f^{2}\right)$ : 
Downstream distance (miles): Town: Year Built:

Highway No. : Structure No. : Structure Type:

Clear span (ft): Clear Height $(f t)$ : Full Waterway $\left(f^{2}\right)$ :

Comments:

noted as consisting of stone and gravel with a few boulders. A shallow sand point bar has developed along the left abutment.

\section{USGS Watershed Data}

Watershed Hydrographic Data

Drainage area $(D A) \underline{16.58} m$

Watershed storage (ST)

Bridge site elevation

Main channel length

779
$\mathrm{mi}^{2}$

Lake/pond/swamp area $\mathbf{0}$ $\mathrm{mi}^{2}$ $\%$ $10 \%$ channel length elevation $\mathbf{8 0 0}$ $\mathrm{ft} \quad 85 \%$ channel length elevation 1720 $\mathrm{ft}$

Main channel slope $(S)$

(S) 143.13 $\mathrm{ft} / \mathrm{mi}$

Watershed Precipitation Data

Average site precipitation in Average headwater precipitation in

Maximum 2yr-24hr precipitation event $(124,2)$ in

Average seasonal snowfall (Sn) $\mathrm{ft}$ 


\section{Bridge Plan Data}

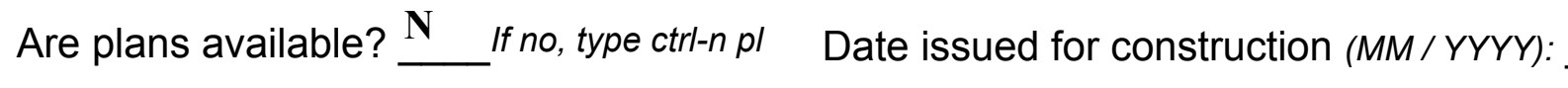

Project Number

Minimum channel bed elevation:

Low superstructure elevation: USLAB DSLAB USRAB DSRAB Benchmark location description:

NO BENCHMARK INFORMATION

Reference Point (MSL, Arbitrary, Other): Datum (NAD27, NAD83, Other):

Foundation Type: 4

If 1 : Footing Thickness

If 2: Pile Type:

If 3: Footing bottom elevation:

Is boring information available? $\mathbf{N}$

Foundation Material Type: $\mathbf{3}$

(1-Spreadfooting; 2-Pile; 3- Gravity; 4-Unknown)

Footing bottom elevation: -

Briefly describe material at foundation bottom elevation or around piles:

NO FOUNDATION MATERIAL INFORMATION

Comments:

NO PLANS. 


\section{Cross-sectional Data}

Is cross-sectional data available? Yes If no, type ctrl-n xs

Source (FEMA, VTAOT, Other)? FEMA

Comments:

\begin{tabular}{|l|l|l|l|l|l|l|l|l|l|l|l|}
\hline Station & $\mathbf{0}$ & $\mathbf{6}$ & $\mathbf{1 2}$ & $\mathbf{1 8}$ & $\mathbf{2 4}$ & $\mathbf{3 0 . 5}$ & - & - & - & - & - \\
\hline Feature & LAB & - & - & - & - & RAB & - & - & - & - & - \\
\hline $\begin{array}{l}\text { Low chord } \\
\text { elevation }\end{array}$ & $\mathbf{7 7 0 . 9}$ & $\mathbf{7 7 0 . 9}$ & $\mathbf{7 7 0 . 9}$ & $\mathbf{7 7 0 . 9}$ & $\mathbf{7 7 0 . 9}$ & $\mathbf{7 7 0 . 9}$ & - & - & - & - & - \\
\hline $\begin{array}{l}\text { Bed } \\
\text { elevation }\end{array}$ & 763.8 & $\mathbf{7 6 1 . 6}$ & $\mathbf{7 6 0 . 0}$ & $\mathbf{7 5 9 . 7}$ & $\mathbf{7 5 9 . 6}$ & $\mathbf{7 6 0 . 3}$ & - & - & - & - & - \\
\hline $\begin{array}{l}\text { Low chord } \\
\text { to bed }\end{array}$ & $\mathbf{7 . 1}$ & $\mathbf{9 . 3}$ & $\mathbf{1 0 . 9}$ & $\mathbf{1 1 . 2}$ & $\mathbf{1 1 . 3}$ & $\mathbf{1 0 . 6}$ & - & - & - & - & - \\
\hline Station & - & - & - & - & - & - & - & - & - & - & - \\
\hline Feature & - & - & - & - & - & - & - & - & - & - & - \\
\hline $\begin{array}{l}\text { Low chord } \\
\text { elevation }\end{array}$ & - & - & - & - & - & - & - & - & - & - & - \\
\hline $\begin{array}{l}\text { Bed } \\
\text { elevation }\end{array}$ & - & - & - & - & - & - & - & - & - & - & - \\
\hline $\begin{array}{l}\text { Low chord } \\
\text { to bed }\end{array}$ & - & - & - & - & - & - & - & - & - & - & - \\
\hline
\end{tabular}

Source (FEMA, VTAOT, Other)?

Comments: -

\begin{tabular}{|l|l|l|l|l|l|l|l|l|l|l|l|}
\hline Station & - & - & - & - & - & - & - & - & - & - & - \\
\hline Feature & - & - & - & - & - & - & - & - & - & - & - \\
\hline $\begin{array}{l}\text { Low chord } \\
\text { elevation }\end{array}$ & - & - & - & - & - & - & - & - & - & - & - \\
\hline $\begin{array}{l}\text { Bed } \\
\text { elevation }\end{array}$ & - & - & - & - & - & - & - & - & - & - & - \\
\hline $\begin{array}{l}\text { Low chord } \\
\text { to bed }\end{array}$ & - & - & - & - & - & - & - & - & - & - & - \\
\hline Station & - & - & - & - & - & - & - & - & - & - & - \\
\hline Feature & - & - & - & - & - & - & - & - & - & - & - \\
\hline $\begin{array}{l}\text { Low chord } \\
\text { elevation }\end{array}$ & - & - & - & - & - & - & - & - & - & - & - \\
\hline $\begin{array}{l}\text { Bed } \\
\text { levation }\end{array}$ & - & - & - & - & - & - & - & - & - & - & - \\
\hline $\begin{array}{l}\text { Low chord } \\
\text { to bed }\end{array}$ & - & - & - & - & - & - & - & - & - & - & - \\
\hline
\end{tabular}




\section{APPENDIX E: \\ LEVEL I DATA FORM}


U. S. Geological Survey

Bridge Field Data Collection and Processing Form

Qa/Qc Check by: JRD Date: $\mathbf{5 / 2 8 / 9 7}$

\section{Structure Number WWINTH00370034}

Computerized by: $\underline{\mathbf{E W}}$ Date: 6 /97

Reviewd by: $\quad$ EMB Date: 9/1/98

\section{A. General Location Descriptive}

1. Data collected by (First Initial, Full last name) $\underline{\mathbf{R}}$. Burns

2. Highway District Number 04

County Windsor (027)

Mile marker $\mathbf{0}$

Waterway (I - 6) Mill Brook

Route Number TH 37

Date $(M M / D D / Y Y) \underline{06} / \underline{05} / 1996$

3. Descriptive comments:

Town West Windsor (83050)

Road Name -

Hydrologic Unit Code: $\mathbf{0 1 0 8 0 1 0 4}$

This structure is located six hundredths of a mile from a junction with State Route 44. The structure is a covered bridge with concrete faced abutments and laid up stone wingwalls.

\section{B. Bridge Deck Observations}
4. Surface cover... LBUS 5
RBUS 4
LBDS 4
RBDS 4
Overall 4

(2b us, ds,lb,rb: 1- Urban; 2- Suburban; 3- Row crops; 4- Pasture; 5- Shrub- and brushland; 6- Forest; 7- Wetland)
5. Ambient water surface... US 1
UB 1
DS 1
(1- pool; 2- riffle)

6. Bridge structure type 1 (1- single span; 2- multiple span; 3- single arch; 4- multiple arch; 5-cylindrical culvert; 6- box culvert; or 7- other)

7. Bridge length $\underline{\mathbf{3 7}}$

(feet)

Span length $\underline{\mathbf{3 2}}$

(feet)

Bridge width 12.3 (feet)

\section{Road approach to bridge:}
8. LB $\underline{1}$ RB 1
( 0 even, 1- lower, 2- higher)
9. LB 2 RB $\underline{2}$
(1-Paved, 2- Not paved)

10. Embankment slope (run / rise in feet / foot):

US left

US right

\begin{tabular}{|l|l|l|l|}
\hline \multicolumn{2}{|c|}{ Protection } & \multirow{2}{*}{ 13.Erosion } & 14.Severity \\
\hline 11.Type & 12.Cond. & & \\
\hline
\end{tabular}

LBUS

RBUS

RBDS

LBDS

\begin{tabular}{l|l|}
\hline $\mathbf{0}$ & - \\
\hline $\mathbf{0}$ & - \\
\hline $\mathbf{0}$ & - \\
\hline $\mathbf{0}$ & - \\
\hline
\end{tabular}

\begin{tabular}{l}
\hline $\mathbf{0}$ \\
\hline 2 \\
\hline 0
\end{tabular}

Bank protection types: 0- none; 1- < 12 inches,

2- $<36$ inches; $3-<48$ inches

4- < 60 inches; 5- wall / artificial levee

Bank protection conditions: 1- good; 2- slumped;

3- eroded; 4- failed

Erosion: 0 - none; 1- channel erosion; 2 -

road wash; 3- both; 4- other

Erosion Severity: 0 - none; 1- slight; 2- moderate; 3- severe

\section{Channel approach to bridge (BF):}

15. Angle of approach: $\mathbf{5 5}$

16. Bridge skew: $\mathbf{1 0}$

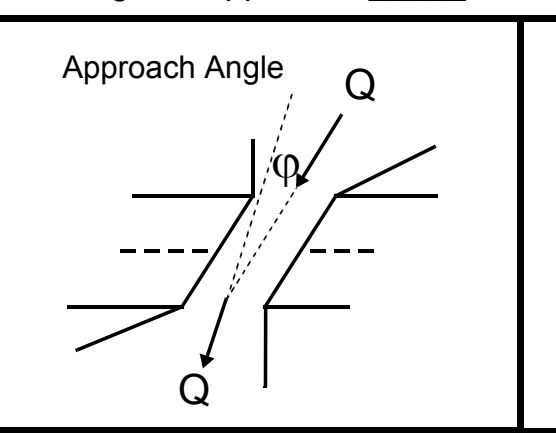

17. Channel impact zone 1:

Where? RB (LB, RB)

Exist? $\mathbf{Y}(Y$ or $N)$

Bridge Skew Angle

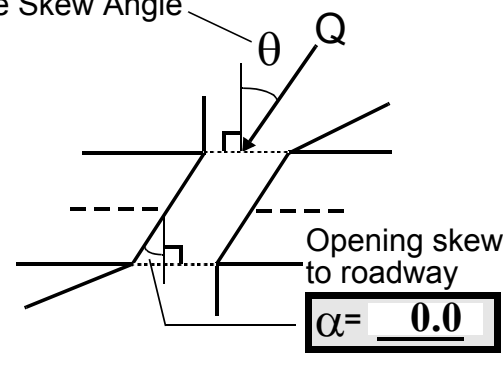

Range? 18

feet US

Severity 1

Channel impact zone 2:

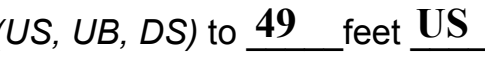

Where? LB (LB, RB)

Exist? $\underline{\mathbf{Y}}(\mathrm{Y}$ or $N)$

Range? $\underline{\mathbf{3 0}}$ feet $\underline{\mathbf{D S}}$

Severity $\underline{2}$

Impact Severity: 0- none to very slight; 1- Slight; 2- Moderate; 3- Severe 
18. Bridge Type: 1a

1a- Vertical abutments with wingwalls

1 b- Vertical abutments without wingwalls

2- Vertical abutments and wingwalls, sloping embankment Wingwalls parallel to abut. face

3- Spill through abutments

4- Sloping embankment, vertical wingwalls and abutments

Wingwall angle less than $90^{\circ}$.

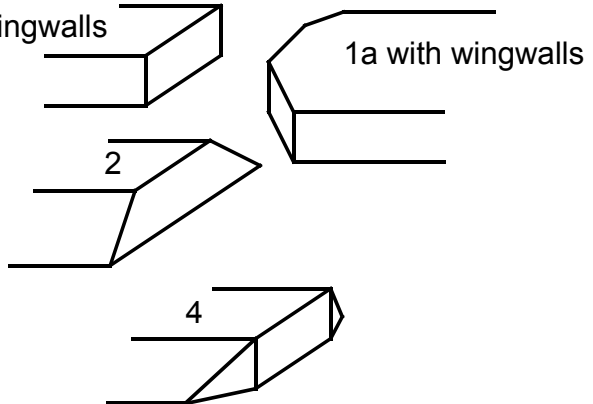

19. Bridge Deck Comments (surface cover variations, measured bridge and span lengths, bridge type variations, approach overflow width, etc.)

4. The upstream left bank surface cover includes shrubs, brush, a barn and a dirt road entering the stream. The upstream right bank has trees along the bank, and a continuation of the road from the left bank into the pasture. The downstream left bank has trees along the bank and a house with a lawn beyond two bridge lengths. The downstream right bank has shrubs along the bank and a dirt road paralleling the stream through the pasture.

7. The measured bridge length is 38 feet, the span length is $\mathbf{3 0 . 5}$ feet, and the width is $\mathbf{1 2 . 4}$ feet.

8. The left road approach slopes down from the bridge and back up towards state route 44.

\section{Upstream Channel Assessment}

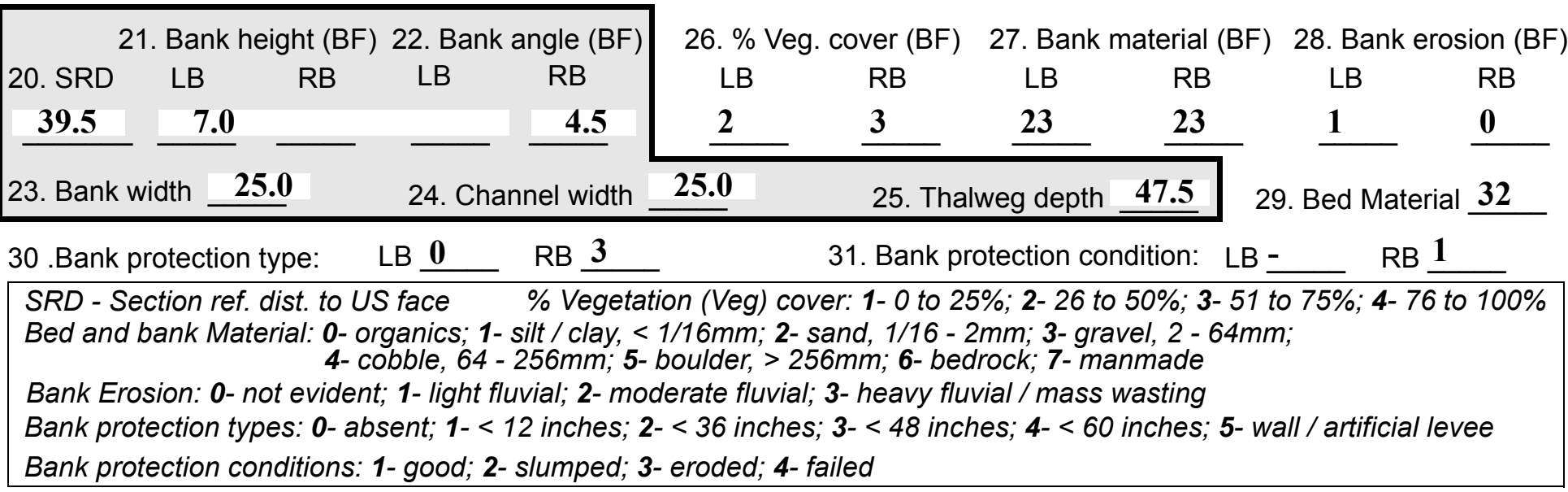

32. Comments (bank material variation, minor inflows, protection extent, etc.):

30. The right bank protection extends from fifty seven feet upstream to the upstream right wing wall. The dirt road crosses the stream one hundred and ten feet upstream of the structure. 
33.Point/Side bar present? $\mathbf{Y}$

$(Y$ or $N$. if $N$ type ctrl-n pb) 34 . Mid-bar distance: 27

35. Mid-bar width: $\mathbf{5}$

36. Point bar extent: 36 feet $\underline{\text { US }}$

(US, UB) to 6 feet $\underline{\text { DS }}$

(US, UB, DS) positioned 0 $\%$ LB to $15 \%$ RB

37. Material: 2

38. Point or side bar comments (Circle Point or Side; Note additional bars, material variation, status, etc.):

The point bar is vegetated except for the portion under the bridge.

39. Is a cut-bank present? $\mathbf{N}$ ( $Y$ or if $N$ type ctrl- $n c b)$

40. Where? - $\quad$ (LB or RB)

41. Mid-bank distance: -

42. Cut bank extent: -

feet -

(US, UB) to feet (US, UB, DS)

43. Bank damage: -

(1- eroded and/or creep; 2- slip failure; 3- block failure)

44. Cut bank comments (eg. additional cut banks, protection condition, etc.):

NO CUT BANKS

\section{Is channel scour present? $\mathbf{Y}$ ( $Y$ or if $N$ type ctrl-n cs)}

46. Mid-scour distance: 4

47. Scour dimensions: Length $\mathbf{7 2}$

Width 11

Depth : 2.5

Position 60 \%LB to 100 \%RB

48. Scour comments (eg. additional scour areas, local scouring process, etc.):

The scour hole extends from 40 feet upstream to 20 feet downstream. The scour depth is based on a 1.5 foot average thalweg depth measured elsewhere in the upstream reach.

49. Are there major confluences? $\mathbf{N}$

51. Confluence 1: Distance -

Confluence 2: Distance -

Confluence 2. Distance

54. Confluence comments (eg. confluence name):

NO MAJOR CONFLUENCES
( $Y$ or if $N$ type ctrl-n $m c)$

52. Enters on -

Enters on (LB or $R B)$ (LB or $R B)$
50. How many? -

53. Type(1- perennial; 2- ephemeral)

Type (1-perennial; 2- ephemeral)

\section{Under Bridge Channel Assessment}

55. Channel restraint (BF)? LB 2

\begin{tabular}{|cccc}
\hline \multicolumn{2}{|c}{ 56. Height (BF) } & \multicolumn{2}{c}{57 Angle (BF) } \\
LB & RB & LB & RB \\
$\mathbf{2 2 . 5}$ & & $\mathbf{2 . 5}$ & \\
\hline
\end{tabular}

58. Bank width (BF) (1- natural bank; 2- abutment; 3- artificial levee)

Bed and bank Material: 0- organics; 1- silt / clay, < 1/16mm; 2- sand, 1/16 - 2mm; 3- gravel, 2 - 64mm; 4- cobble, 64 - 256mm; 5- boulder, > 256mm; 6- bedrock; 7- manmade

Bank Erosion: 0- not evident; 1- light fluvial; 2- moderate fluvial; 3- heavy fluvial / mass wasting

64. Comments (bank material variation, minor inflows, protection extent, etc.):

23 
65. Debris and Ice Is there debris accumulation?

$(Y$ or $N)$ 66. Where? $\mathbf{N}$

(1- Upstream; 2- At bridge; 3- Both)

67. Debris Potential ( 1- Low; 2- Moderate; 3- High)

68. Capture Efficiency 2

(1-Low; 2- Moderate; 3- High)

69. Is there evidence of ice build-up? 2

Ice Blockage Potential $\underline{\mathbf{Y}}$

(1- Low; 2- Moderate; 3- High)

70. Debris and Ice Comments:

2

67. The vine and dead trees along the banks contribute to the debris potential.

68. The bend in the upstream reach increases the capture efficiency.

69. Trees on the upstream right bank have ice scaring.

\begin{tabular}{|l|c|c|c|c|c|c|c|c|}
\hline Abutments & $\begin{array}{c}\text { 71. Attack } \\
\angle \text { (BF) }\end{array}$ & $\begin{array}{c}\text { 72. Slope } \angle \\
\text { (Qmax) }\end{array}$ & $\begin{array}{c}\text { 73. Toe } \\
\text { loc. (BF) }\end{array}$ & $\begin{array}{c}\text { 74. Scour } \\
\text { Condition }\end{array}$ & $\begin{array}{c}75 . \text { Scour } \\
\text { depth }\end{array}$ & $\begin{array}{c}\text { 76. Exposure } \\
\text { depth }\end{array}$ & 77. Material & 78. Length \\
\hline LABUT & & - & $\mathbf{9 0}$ & $\mathbf{2}$ & $\mathbf{0}$ & - & - & $\mathbf{9 0 . 0}$ \\
\hline RABUT & $\mathbf{1}$ & $\mathbf{1 0}$ & $\mathbf{9 0}$ & & & $\mathbf{2}$ & $\mathbf{1}$ & $\mathbf{2 9 . 5}$ \\
\hline
\end{tabular}

Pushed: $L B$ or RB

Toe Location (Loc.): 0- even, 1- set back, 2- protrudes

Scour cond.: 0- not evident; 1- evident (comment); 2- footing exposed; 3-undermined footing; 4- piling exposed; 5- settled; 6- failed

Materials: 1- Concrete; 2- Stone masonry or drywall; 3- steel or metal; 4- wood

79. Abutment comments (eg. undermined penetration, unusual scour processes, debris, etc.):

1.5

$\mathbf{0}$

1

74. The scour condition noted along the right abutment is a result of the scour hole explained in the upstream channel assessment.

80. Wingwalls:

Exist? Material? Scour Scour Exposure $\begin{aligned} & 81 . \\ & \text { Angle? Length? }\end{aligned}$ Condition? depth? depth?

USLWW:

Wingwall materials: 1- Concrete; 2- Stone masonry or drywall; 3- steel or metal; 4- wood

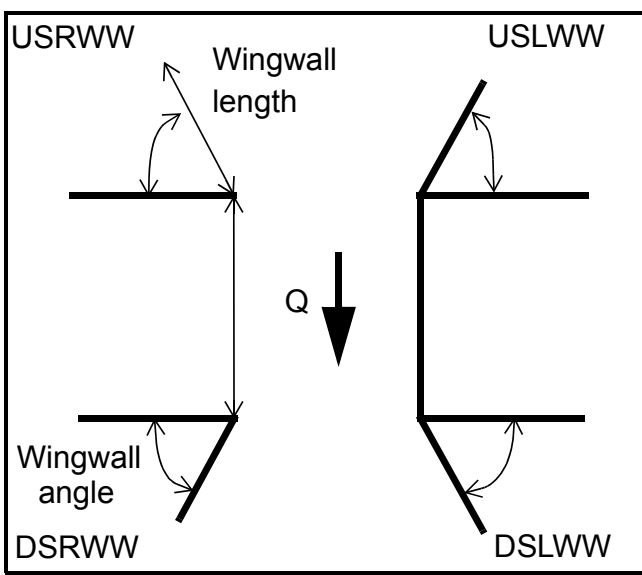

82. Bank / Bridge Protection:

\begin{tabular}{|l|l|l|l|l|l|l|c|c|}
\hline Location & USLWW & USRWW & LABUT & RABUT & LB & RB & DSLWW & DSRWW \\
\hline Type & $\mathbf{0}$ & $\mathbf{0}$ & $\mathbf{Y}$ & $\mathbf{1 . 5}$ & - & $\mathbf{1}$ & - & $\mathbf{1}$ \\
\hline Condition & $\mathbf{Y}$ & - & $\mathbf{2}$ & $\mathbf{0}$ & - & $\mathbf{2}$ & - & $\mathbf{1}$ \\
\hline Extent & $\mathbf{2}$ & - & $\mathbf{1}$ & $\mathbf{0}$ & $\mathbf{4}$ & - & $\mathbf{3}$ & - \\
\hline
\end{tabular}

Bank / Bridge protection types: 0- absent; 1- < 12 inches; 2- < 36 inches; 3- < 48 inches; 4- < 60 inches; 
83. Wingwall and protection comments (eg. undermined penetration, unusual scour processes, etc.):

-
-
-
-
-
0
-
-
0
-
-

\section{Piers:}

84. Are there piers? 80. (Y or if $N$ type ctrl-n pr)

\begin{tabular}{|l|l|l|l|l|l|l|l|}
\hline \multirow{2}{*}{$\begin{array}{l}85 . \\
\text { Pier no. }\end{array}$} & \multicolumn{3}{|c|}{ width (w) feet } & \multicolumn{3}{c|}{ elevation (e) feet } \\
\cline { 2 - 8 } & w1 & w2 & w3 & e@w1 & e@w2 & e@w3 \\
\hline Pier 1 & & & & $\mathbf{5 5 . 0}$ & $\mathbf{1 3 . 0}$ & $\mathbf{5 0 . 0}$ \\
\hline Pier 2 & & & & $\mathbf{1 2 . 5}$ & $\mathbf{5 0 . 0}$ & $\mathbf{1 2 . 5}$ \\
\hline Pier 3 & & & - & $\mathbf{5 5 . 0}$ & $\mathbf{1 2 . 5}$ & - \\
\hline Pier 4 & - & - & - & - & - & - \\
\hline
\end{tabular}

\begin{tabular}{|l|l|l|l|l|}
\hline Level 1 Pier Descr. & \multicolumn{1}{|c|}{1} & \multicolumn{1}{|c|}{2} & \multicolumn{1}{|c|}{3} & \multicolumn{1}{|c|}{4} \\
\hline 86. Location (BF) & The & describ & left & was \\
\hline 87. Type & scou & ed in & abut & foun \\
\hline 88. Material & r & the & ment & d by \\
\hline 89. Shape & hole & upst & pro- & prob \\
\hline 90. Inclined? & at & ream & tec- & ing \\
\hline 91. Attack $\angle$ (BF) & the & chan & tion & with \\
\hline 92. Pushed & right & nel & is & a \\
\hline 93. Length (feet) & - & - & - & - \\
\hline 94. \# of piles & wing & asses & cov- & rang \\
\hline 95. Cross-members & walls & smen & ered & e \\
\hline 96. Scour Condition & is the & t. & in & pole. \\
\hline 97. Scour depth & same & $\mathbf{8 2 .}$ & sand, & \\
\hline 98. Exposure depth & one & The & and & \\
\hline
\end{tabular}

LFP, LTB, LB, MCL, MCM, MCR, RB, RTB, RFP

1- Solid pier, 2- column, 3- bent

1-Wood; 2- concrete; 3- metal; 4- stone

1- Round; 2- Square; 3- Pointed

Y-yes; $N$ - no

$L B$ or $R B$

0- none; 1- laterals; 2- diagonals; 3- both

0- not evident; 1- evident (comment);

2- footing exposed; 3- piling exposed;

4- undermined footing; 5- settled; 6- failed 
99. Pier comments (eg. undermined penetration, protection and protection extent, unusual scour processes, etc.):

$\mathbf{N}$

100.

\section{E. Downstream Channel Assessment}

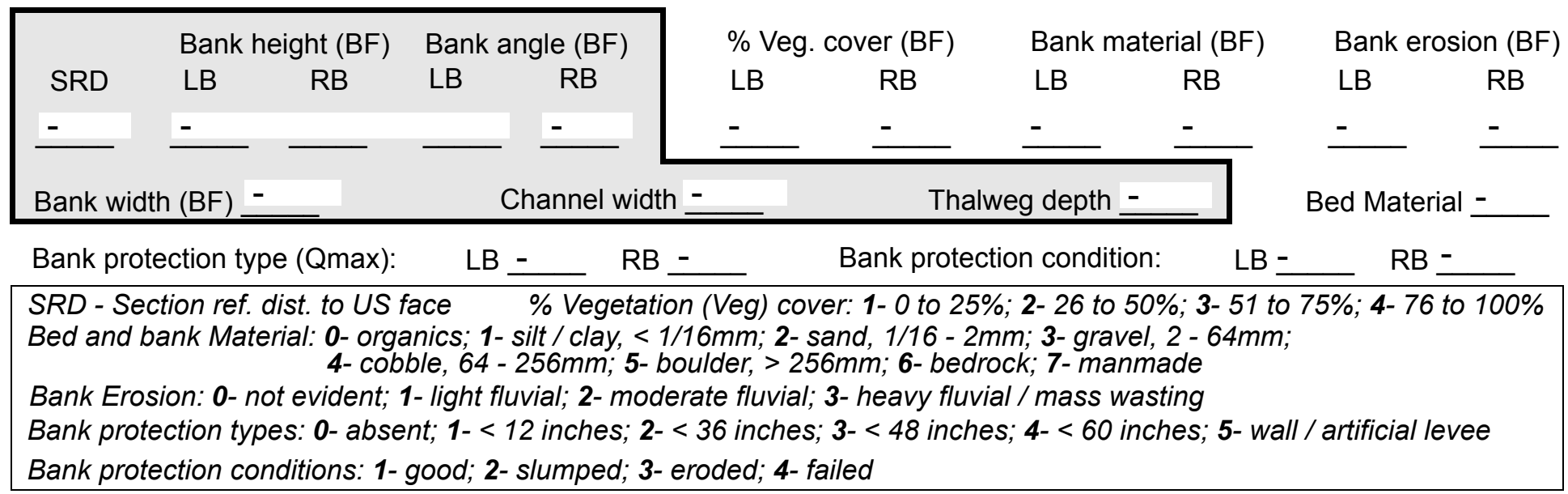

Comments (eg. bank material variation, minor inflows, protection extent, etc.):$$
-
$$$$
-
$$

$-$

$-$

$-$

$-$

$-$

$-$

$-$

$-$

$-$

$-$

$-$

$-$

$-$

\section{Is a drop structure present? __ ( $Y$ or $N$, if $N$ type ctrl-n ds) 102. Distance: ___ feet}

103. Drop: -_ feet 104. Structure material: ___ (1- steel sheet pile; 2- wood pile; 3- concrete; 4- other)

105. Drop structure comments (eg. downstream scour depth):

$-$

$-$

$-$

-

-

- 
106. Point/Side bar present? (Y or $N$. if $N$ type ctrl-n pb)Mid-bar distance:

Mid-bar width: -

Point bar extent: feet -

(US, UB, DS) to feet (US, UB, DS) positioned $\%$ LB to $\% \mathrm{RB}$ Material:

Point or side bar comments (Circle Point or Side; note additional bars, material variation, status, etc.):

$-$

\section{NO PIERS}

\section{Is a cut-bank present?}

Cut bank extent: feet (US, UB, DS) to (1- eroded and/or creep; 2- slip failure; 3- block failure)

Bank damage:

Cut bank comments (eg. additional cut banks, protection condition, etc.): 1

1

23

23

Is channel scour present? ( $Y$ or if $N$ type ctrl-n cs) Width $\mathbf{0}$ Depth: 0 Mid-scour distance: $\underline{1}$ sctin

Scour comments (eg. additional scour areas, local scouring process, etc.):

There is a large tree, 30 feet downstream on the left bank that is being undermined, up to 1 foot horizontally.

\section{Are there major confluences?} ( $Y$ or if $N$ type ctrl-n mc)

How many?

Confluence 1: Distance Enters on (LB or RB)

Type (1- perennial; 2- ephemeral) Confluence 2: Distance Enters on ( $L B$ or $R B)$

Type (1- perennial; 2- ephemeral) Confluence comments (eg. confluence name):

\section{F. Geomorphic Channel Assessment}

107. Stage of reach evolution
1- Constructed

2- Stable

3- Aggraded

4- Degraded

5- Laterally unstable

6- Vertically and laterally unstable 
108. Evolution comments (Channel evolution not considering bridge effects; See HEC-20, Figure 1 for geomorphic descriptors):

$\mathbf{N}$

$-$

NO DROP STRUCTURE

Y

60

16

30

DS 


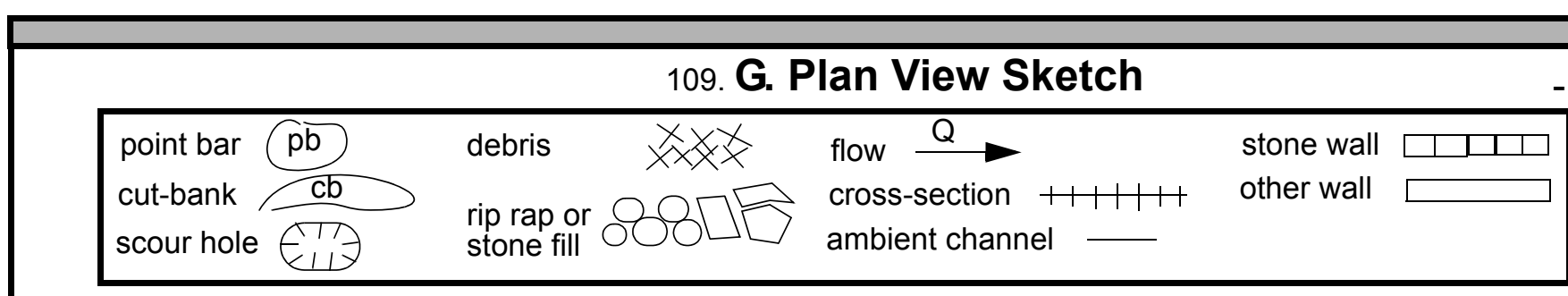


APPENDIX F:

SCOUR COMPUTATIONS 
SCOUR COMPUTATIONS

\begin{tabular}{|c|c|c|c|}
\hline $\begin{array}{ll}\text { Structure Number: } & \text { WWINTH00370034 } \\
\text { Road Number: } & \text { TH } 37 \\
\text { Stream: } & \text { Mill Brook }\end{array}$ & & $\begin{array}{l}\text { Town: } \\
\text { County: }\end{array}$ & $\begin{array}{l}\text { West Windsor } \\
\text { Windsor }\end{array}$ \\
\hline Initials EMB & Checked: & $\mathrm{ECW}$ & \\
\hline \multicolumn{4}{|c|}{ Analysis of contraction scour, live-bed or clear water? } \\
\hline \multicolumn{4}{|c|}{$\begin{array}{l}\text { Critical Velocity of Bed Material (converted to English units) } \\
\text { VC=11.21*y } 1^{\wedge} 0.1667 * \mathrm{D} 50^{\wedge} 0.33 \text { with } \mathrm{Ss}=2.65 \\
\text { (Richardson and Davis, } 1995, \mathrm{p} .28, \text { eq. 16) }\end{array}$} \\
\hline \\
\hline Characteristic & $100 \mathrm{yr}$ & $500 \mathrm{yr}$ & other Q \\
\hline $\begin{array}{l}\text { Total discharge, cfs } \\
\text { Main Channel Area, ft2 } \\
\text { Left overbank area, ft2 } \\
\text { Right overbank area, ft2 } \\
\text { Top width main channel, ft } \\
\text { Top width L overbank, ft } \\
\text { Top width o overbank, ft } \\
\text { D50 of channel, ft } \\
\text { D50 left overbank, ft } \\
\text { D50 right overbank, ft }\end{array}$ & $\begin{array}{l}3500 \\
319 \\
84 \\
1108 \\
47 \\
84 \\
471 \\
0.142 \\
-- \\
--\end{array}$ & $\begin{array}{l}5200 \\
342 \\
127 \\
1340 \\
47 \\
91 \\
473 \\
0.142 \\
-- \\
--\end{array}$ & $\begin{array}{l}1460 \\
243 \\
0 \\
342 \\
45 \\
0 \\
463 \\
0.142 \\
-- \\
--\end{array}$ \\
\hline $\begin{array}{l}\text { Y1, average depth, } \mathrm{MC}, \mathrm{ft} \\
\text { Y1, average depth, LOB, ft } \\
\mathrm{Y}^{1,} \text { average depth, ROB, ft }\end{array}$ & $\begin{array}{l}6.8 \\
1.0 \\
2.4\end{array}$ & $\begin{array}{l}7.3 \\
1.4 \\
2.8\end{array}$ & $\begin{array}{l}5.4 \\
\operatorname{ERR} \\
0.7\end{array}$ \\
\hline $\begin{array}{l}\text { Total conveyance, approach } \\
\text { Conveyance, main channel } \\
\text { Conveyance, LOB } \\
\text { Conveyance, ROB } \\
\text { Percent discrepancy, conveyance } \\
\text { Qm, discharge, MC, Cfs } \\
\text { Ql, discharge, LOB, Cfs } \\
\text { Qr, discharge, ROB, Cfs }\end{array}$ & $\begin{array}{l}110607 \\
35505 \\
2082 \\
73019 \\
0.0009 \\
1123.5 \\
65.9 \\
2310.6\end{array}$ & $\begin{array}{l}143661 \\
39909 \\
3932 \\
99819 \\
0.0007 \\
1444.6 \\
142.3 \\
3613.1\end{array}$ & $\begin{array}{l}33572 \\
23155 \\
0 \\
10417 \\
0.0000 \\
1007.0 \\
0.0 \\
453.0\end{array}$ \\
\hline $\begin{array}{l}\text { Vm, mean velocity } \mathrm{MC}, \mathrm{ft} / \mathrm{s} \\
\mathrm{Vl} \text {, mean velocity, LOB, ft/s } \\
\text { Vr, mean velocity, ROB, ft/s } \\
\text { VC-m, crit. velocity, MC, ft/s } \\
\text { Vc-l, crit. velocity, LOB, ft/s } \\
\text { Vc-r, crit. velocity, } \mathrm{ROB}, \mathrm{ft} / \mathrm{s}\end{array}$ & $\begin{array}{l}3.5 \\
0.8 \\
2.1 \\
8.0 \\
\text { ERR } \\
\text { ERR }\end{array}$ & $\begin{array}{l}4.2 \\
1.1 \\
2.7 \\
8.1 \\
\text { ERR } \\
\text { ERR }\end{array}$ & $\begin{array}{l}4.1 \\
\text { ERR } \\
1.3 \\
\quad 7.7 \\
\text { ERR } \\
\text { ERR }\end{array}$ \\
\hline \multicolumn{4}{|l|}{ Results } \\
\hline $\begin{array}{l}\text { Live-bed(1) or Clear-Water (0) Cont } \\
\text { Main Channel }\end{array}$ & $\underset{0}{\operatorname{action} \mathrm{S}}$ & $\begin{array}{c}\text { our? } \\
0\end{array}$ & 0 \\
\hline
\end{tabular}




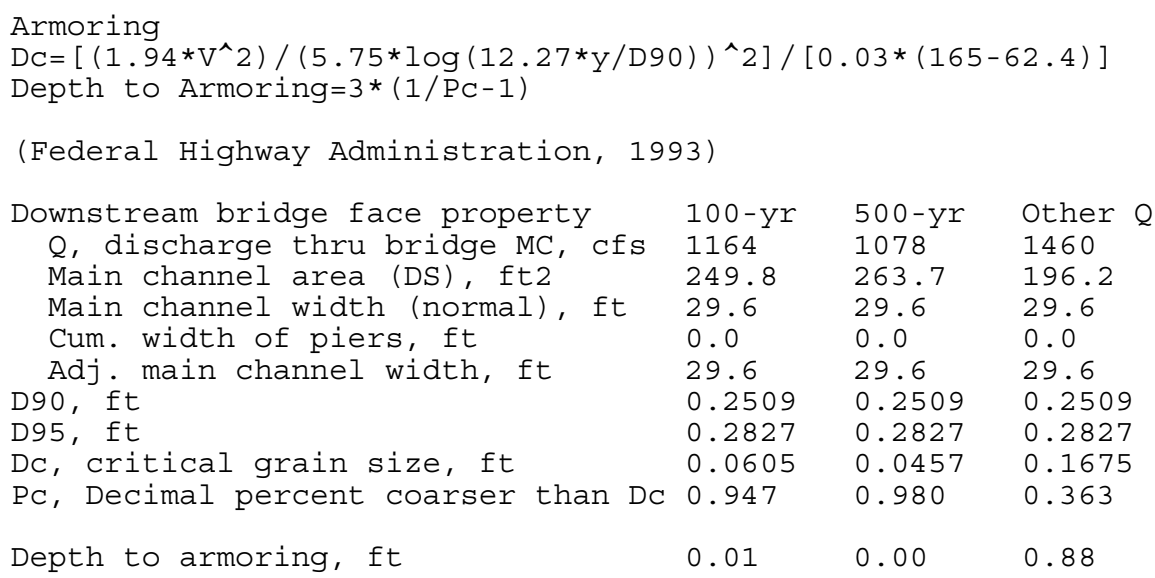


Abutment Scour

Froehlich's Abutment Scour

$\mathrm{Ys} / \mathrm{Y} 1=2.27 * \mathrm{~K} 1 * \mathrm{~K} 2 *\left(\mathrm{a}^{\prime} / \mathrm{Y} 1\right)^{\wedge} 0.43 * \mathrm{Fr} 1 \wedge 0.61+1$

(Richardson and Davis, 1995, p. 48, eq. 28)

Characteristic

(Qt), total discharge, cfs $a^{\prime}$, abut.length blocking flow, ft

Ae, area of blocked flow ft 2

Qe, discharge blocked abut., cfs

Ve, (Qe/Aing Qtotal

ya, depth of $\mathrm{f} / \mathrm{p}$ flow, ft

--Coeff., KI, for abut. typ $\mathrm{K} 1$
Left Abutment $100 \mathrm{yr} Q 500 \mathrm{yr} Q$ Other Q $100 \mathrm{yr} Q 500 \mathrm{yr} Q$ Other Q

--Angle (theta) of embankment (<90 if abut. points DS; >90 if abut. points US)

$\begin{array}{lllllll}\text { theta } & 90 & 90 & 90 & 90 & 90 & 90\end{array}$

K2

$1.00 \quad 1.00$

1.00

1.00

1.00

1.00

Fr, froude number $\mathrm{f} / \mathrm{p}$ flow

0.171

0.184

0.173

0.241

0.283

0.285

ys, scour depth, ft

6.49

7.34

5.67

15.72

17.72

11.61

HIRE equation ( $\left.\mathrm{a}^{\prime} / \mathrm{ya}>25\right)$

$\mathrm{Ys}=4 * \mathrm{Fr}^{\wedge} 0.33 * \mathrm{Y} 1 * \mathrm{~K} / 0.55$

(Richardson and Davis, 1995, p. 49, eq. 29)

$a^{\prime}$ (abut length blocked, ft)

yl (depth $\mathrm{f} / \mathrm{p}$ flow, ft)

$a^{\prime} / y^{1}$

Skew correction (p. 49, fig. 16)

Froude no. f/p flow

92.2

1.31

70.20

1.00

0.17

1.44

68.72

6.1
3.05

3.05

1.00

2.00

1.53

313.79

1.00

1.00

483.2

473.1

Ys w/ corr. factor K1/0.55:

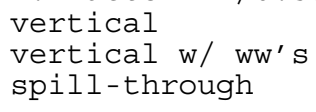

vertical w/ $\mathrm{ww}^{\prime} \mathrm{s}$

spill-through

5.33

0.18

0.17

0.24

300.65

0.80

4.37

6.01

4. 92

\section{ERR}

6.97

0.28

89.32

1.00

2.93

3.30

ERR

5.71

7.71

0.29

Abutment riprap Sizing

Isbash Relationship

$\mathrm{D} 50=\mathrm{Y}^{\star} \mathrm{K}^{\star} \mathrm{Fr} \mathrm{r}^{\wedge} 2 /(\mathrm{SS}-1)$ and $\mathrm{D} 50=\mathrm{Y}^{*} \mathrm{~K} *\left(\mathrm{Fr} \mathrm{r}^{\wedge} 2\right)^{\wedge} 0.14 /(\mathrm{SS}-1)$

(Richardson and Davis, 1995, p112, eq. 81,82)

Characteristic

Q100

Q500

Other Q Q100

Q500

Other Q

Fr, Froude Number

$y$, depth of flow in bridge, ft

0.29

0.25

0.51

0.29

0.25

0.51

Median Stone Diameter for riprap at: left abutment

6.63

8.44

8.91

6.63

right abutment, ft

Fr $<=0.8$ (vertical abut.)

$0.44 \quad 0.34$

1.07

0.44

0.34

ERR

1.07

ERR

ERR

ERR 